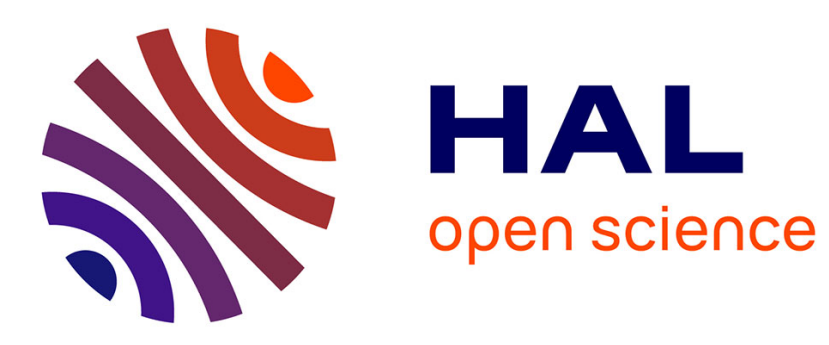

\title{
Influence of Microbial Symbionts on Plant-Insect Interactions
}

\author{
David Giron, F. Dedeine, G. Dubreuil, E. Huguet, L. Mouton, Yannick
}

Outreman, F. Vavre, Jean-Christophe Simon

\section{- To cite this version:}

David Giron, F. Dedeine, G. Dubreuil, E. Huguet, L. Mouton, et al.. Influence of Microbial Symbionts on Plant-Insect Interactions. Nicolas Sauvion, Denis Thiéry, Paul-André Calatayud. Insect-Plant Interactions in a Crop Protection Perspective, 81, Elsevier, Academic Press, pp.225-257, 2017, Advances in Botanical Research, 978-0-12-803318-0. 10.1016/bs.abr.2016.09.007 . hal-02318875

\section{HAL Id: hal-02318875 \\ https://hal.science/hal-02318875}

Submitted on 1 May 2020

HAL is a multi-disciplinary open access archive for the deposit and dissemination of scientific research documents, whether they are published or not. The documents may come from teaching and research institutions in France or abroad, or from public or private research centers.
L'archive ouverte pluridisciplinaire HAL, est destinée au dépôt et à la diffusion de documents scientifiques de niveau recherche, publiés ou non, émanant des établissements d'enseignement et de recherche français ou étrangers, des laboratoires publics ou privés. 


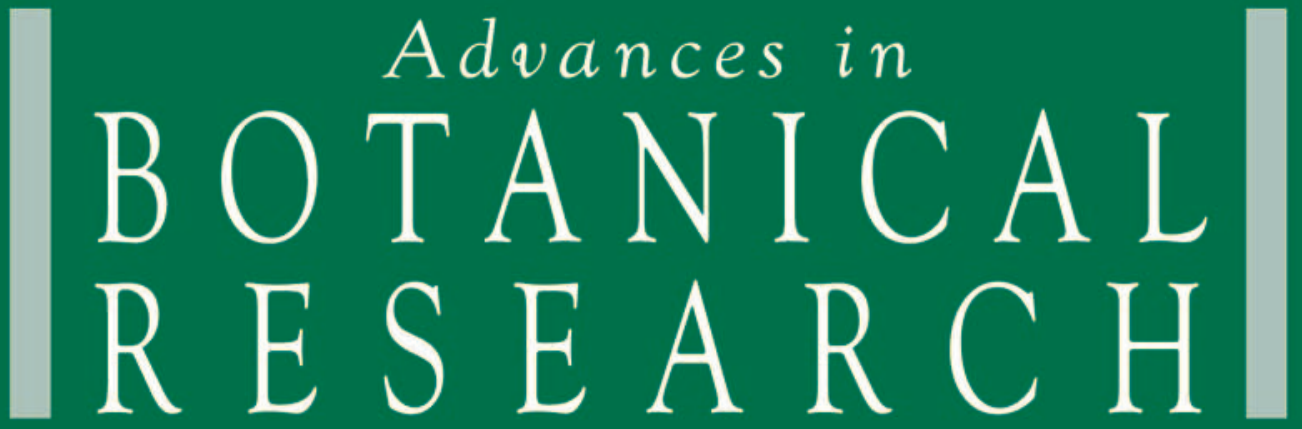

INSECT-PLANT INTERACTIONS IN A CROP PROTECTION PERSPECTIVE

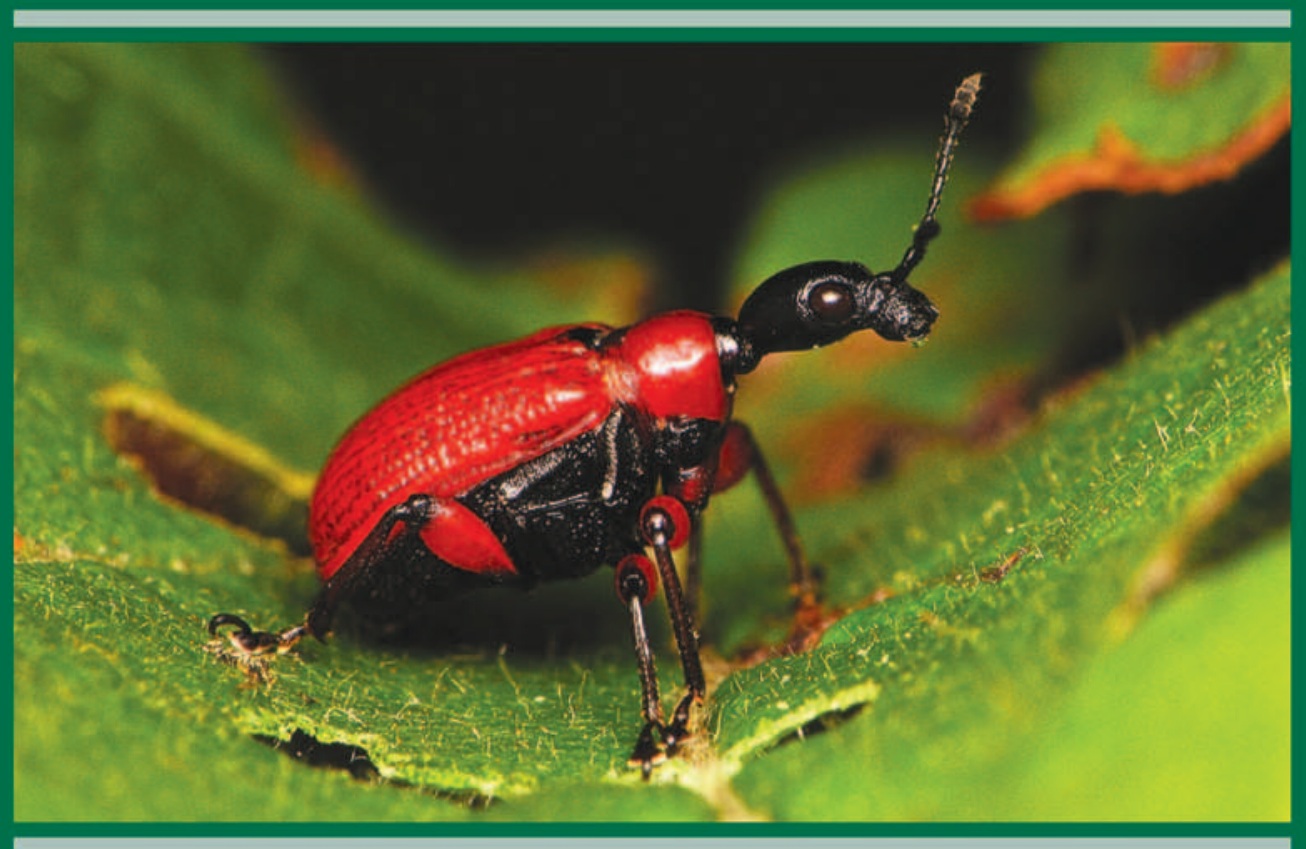

\section{Volume 81}

Edited by

NICOLAS SAUVION, PAUL-ANDRÉ CALATAYUD, DENIS THIÉRY

Series Editors JEAN-PIERRE JACQUOT and PIERRE GADAL

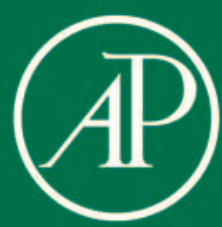




\section{ADVANCES IN BOTANICAL RESEARCH Insect-Plant Interactions in a Crop Protection Perspective}

Volume Editor

\section{NICOLAS SAUVION}

INRA,UMR BGPI 0385 (INRA-CIRAD-SupAgro), Montpellier, France

\section{DENIS THIÉRY}

INRA, UMR SAVE 1065, Bordeaux Sciences Agro,

Centre INRA de recherches de Bordeaux-Aquitaine, Institut des Sciences de la Vigne et du Vin, Villenave d'Ornon, France

\section{PAUL-ANDRÉ CALATAYUD}

IRD UMR EGCE (Evolution, Génome, Comportement, Ecologie), CNRS-IRD-Univ. Paris-Sud, IDEEV, Université Paris-Saclay,

Gif-sur-Yvette, France;

IRD c/o ICIPE, Nairobi, Kenya
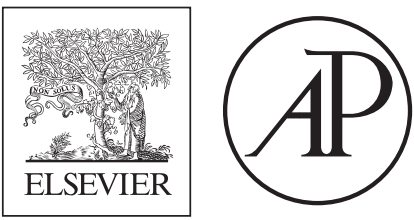

ACADEMIC PRESS

An imprint of Elsevier elsevier.com 
Academic Press is an imprint of Elsevier

125 London Wall, London EC2Y 5AS, United Kingdom

The Boulevard, Langford Lane, Kidlington, Oxford OX5 1GB, United Kingdom

50 Hampshire Street, 5th Floor, Cambridge, MA 02139, United States

525 B Street, Suite 1800, San Diego, CA 92101-4495, United States

First edition 2017

Copyright (C) 2017 Elsevier Ltd. All rights reserved.

No part of this publication may be reproduced or transmitted in any form or by any means, electronic or mechanical, including photocopying, recording, or any information storage and retrieval system, without permission in writing from the publisher. Details on how to seek permission, further information about the Publisher's permissions policies and our arrangements with organizations such as the Copyright Clearance Center and the Copyright Licensing Agency, can be found at our website: www.elsevier.com/permissions.

This book and the individual contributions contained in it are protected under copyright by the Publisher (other than as may be noted herein).

\section{Notices}

Knowledge and best practice in this field are constantly changing. As new research and experience broaden our understanding, changes in research methods, professional practices, or medical treatment may become necessary.

Practitioners and researchers must always rely on their own experience and knowledge in evaluating and using any information, methods, compounds, or experiments described herein. In using such information or methods they should be mindful of their own safety and the safety of others, including parties for whom they have a professional responsibility.

To the fullest extent of the law, neither the Publisher nor the authors, contributors, or editors, assume any liability for any injury and/or damage to persons or property as a matter of products liability, negligence or otherwise, or from any use or operation of any methods, products, instructions, or ideas contained in the material herein.

ISBN: 978-0-12-803318-0

ISSN: 0065-2296

For information on all Academic Press publications visit our website at https://www.elsevier.com

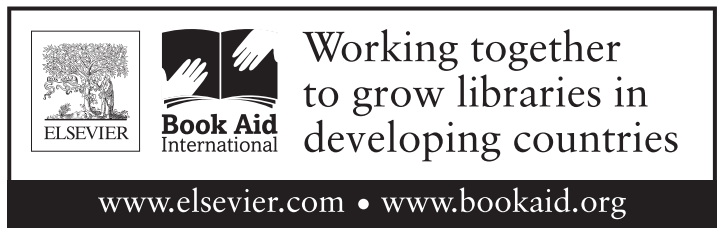

Publisher: Zoe Kruze

Acquisition Editor: Kirsten Shankland

Editorial Project Manager: Hannah Colford

Production Project Manager: Magesh Mahalingam

Designer: Christian Bilbow

Typeset by TNQ Books and Journals 


\section{CONTENTS}

1. Plant-Insect Interactions: A Palaeontological and an Evolutionary Perspective

B. Schatz, N. Sauvion, F. Kjellberg and A. Nel

1. Palaeo-entomology or How We Can Reconstruct the Evolutionary History of Plant-Insect Interactions

2. The First Steps in the Evolutionary History of Plant-Insect Interactions 3

3. The Appearance of Entomophilous Pollination 8

4. Functional Groups of Insect Pollinators and Pollination Syndromes

5. The Mutualism Between Plants and Pollinating Insects and the Radiation of Angiosperms

6. The Entomophilous Pollination: A Never-Ending Source of Problems for Plants

7. The Role of Flower Morphology in Entomophilous Pollination 17

8. Constantly Evolving Insect-plant Interactions 18

References

2. Evolution of Plant-Insect Interactions: Insights From Macroevolutionary Approaches in Plants and Herbivorous Insects

G.J. Kergoat, A.S. Meseguer and E. Jousselin

1. Introduction 26

2. Reconstructing the History of the Associations With Plants 29

3. Conclusion and Perspectives 38

References 43

3. From Plant Exploitation to Mutualism 55

F. Lieutier, K. Bermudez-Torres, J. Cook, M.O. Harris, L. Legal, A. Sallé,

B. Schatz and D. Giron

1. Introduction 56

2. Defence Against Predators $\quad 57$

3. Host Plant Manipulation 67 
4. Mutualism: A Result of Coevolution? Genetic and Functional Aspects 79

5. Conclusion 94

References $\quad 95$

4. Food Webs and Multiple Biotic Interactions in Plant-Herbivore Models

E. Corcket, B. Giffard and R.F.H. Sforza

1. Introduction

2. Food Webs

3. Functional Types of Organisms/Classification of Species Within Food Webs

4. Trophic Cascades From Plants to Insect Predators

5. Applications of Trophic Cascades for Management

6. Nontrophic Interactions in Food Webs

Acknowledgements

References

5. Chemical Signatures in Plant-Insect Interactions

B. Frérot, E. Leppik, A.T. Groot, M. Unbehend and J.K. Holopainen

1. Introduction

2. Plasticity and Specificity of the Chemical Information

3. Plant-Insect Chemical Interaction in Reproduction

4. Plant-Insect Chemical Interaction in Host Finding for Oviposition

5. Conclusion

6. The Plant as a Habitat for Entomophagous Insects

L. Kaiser, P. Ode, S. van Nouhuys, P.-A. Calatayud, S. Colazza,

A.-M. Cortesero, A. Thiel and J. van Baaren

1. Introduction

2. The Plant: Place of Predation and Parasitism 183

3. The Plant, Place of Development 196

4. Effects of Natural Enemies on Plant Defence Traits 200

5. The Plant as Food Source 201

6. The Roles of Local Plant Composition and Landscape Complexity on Diversity, Abundance and Thermotolerance of Entomophagous Insects 
7. Conclusion 211

Acknowledgements $\quad 212$

References $\quad 212$

7. Influence of Microbial Symbionts on Plant-Insect Interactions 225

D. Giron, F. Dedeine, G. Dubreuil, E. Huguet, L. Mouton, Y. Outreman,

F. Vavre and J.-C. Simon

1. Introduction

2. Diversity of Insect Microbial Communities and Ecological Dynamics of Insect Host-Microbe Interactions

3. Direct Effects of Symbionts in Plant-Insect Interactions

4. Indirect Effect of Symbionts in Plant-Insect Interactions: Insect- and Plant-Mediated Indirect Effects

5. Ecological Diversification and Insect Diversification and Specialization 243

6. Conclusion and Outlook 247

Acknowledgements 249

$\begin{array}{ll}\text { References } & 249\end{array}$

8. How Host Plant and Fluctuating Environments Affect Insect Reproductive Strategies?

J. Moreau, E. Desouhant, P. Louâpre, M. Goubault, E. Rajon,

A. Jarrige, F. Menu and D. Thiéry

1. Introduction 260

2. Effect of Host Plant Quality on Male and Female Reproduction 261

3. Insect Reproductive Strategies in Risky Environments 271

4. Conclusions 280

Acknowledgements 281

$\begin{array}{ll}\text { References } & 281\end{array}$

9. Plant-Insect Interactions in a Changing World 289

S. Pincebourde, J. van Baaren, S. Rasmann, P. Rasmont, G. Rodet,

B. Martinet and P.-A. Calatayud

1. Introduction 290

2. Direct Effects of Climate Change on Plant-Insect Interactions 294

3. Indirect Effects of Climate Change on Plant-Insect Interactions 305

4. Impact of Human Activities on Plant-Insect Interactions 312

5. Conclusion and Perspectives 318

Acknowledgements 320

$\begin{array}{ll}\text { References } & 320\end{array}$ 
10. Conservation Biological Control in Agricultural Landscapes

A. Rusch, R. Bommarco and B. Ekbom

1. Introduction

2. Basic Principles in Conservation Biological Control: Provisioning of Key Resources in Space and Time

3. On-field Management Options for Reducing Pest Populations and Enhancing Biological Pest Control

4. Pest Abundance and Biological Control at the Landscape Scale

5. Relationship Between Natural Enemy Community Structure and the Level of Biological Control

6. Conclusions and Future Challenges 354

Acknowledgements $\quad 355$

$\begin{array}{ll}\text { References } & 355\end{array}$

$\begin{array}{ll}\text { Subject Index } & 361\end{array}$

Author Index 369 


\title{
Influence of Microbial Symbionts on Plant-Insect Interactions
}

\author{
D. Giron ${ }^{* 1}{ }^{1}$, F. Dedeine*, G. Dubreuil $*$, E. Huguet*, L. Mouton ${ }^{\S}$,
} Y. Outreman ", F. Vavre ${ }^{\S}$, J.-C. Simon

*Université François-Rabelais de Tours, Centre National de la Recherche Scientifique, Tours, France

${ }^{\S}$ Université de Lyon 1, Centre National de la Recherche Scientifique, Villeurbanne, France

${ }^{\top}$ Agrocampus Ouest, Institut National de la Recherche Scientifique, Université de Rennes 1, Université Bretagne-Loire, Rennes, France

"INRA, UMR 1349 IGEPP INRA-Agrocampus Ouest Rennes-Université Rennes 1, Le Rheu, France

${ }^{1}$ Corresponding author: E-mail: david.giron@univ-tours.fr

\section{Contents}

1. Introduction

2. Diversity of Insect Microbial Communities and Ecological Dynamics of Insect

Host-Microbe Interactions

2.1 Diversity of the Symbionts Associated With Herbivorous Insects

2.2 Characterization of Microbial Diversity in Insects: Identification and Localization 229

2.3 Symbiont Transmission and Acquisition at the Inter-generational Level 230

3. Direct Effects of Symbionts in Plant-Insect Interactions 231

3.1 Influence on Insect Nutrition and Metabolism 231

3.2 Influence on Insect Immunity and Plant Exploitation 232

3.3 Influence on Plant Nutritional Status and Morphology 233

3.4 Impact on Plant Secondary Metabolism/Plant Immunity 234

3.5 Genes Acquired by Horizontal Gene Transfer That Influence Plant-Insect 236 Interactions

4. Indirect Effect of Symbionts in Plant-Insect Interactions: Insect- and Plant-

Mediated Indirect Effects

4.1 Impact on Insect Reproduction

4.2 Interactions With Natural Enemies of Herbivores: Protection Versus Attraction 239

4.3 Interactions With Plant Pathogens: Influence of Insect Symbionts on Plant 242 Pathogen Transmission

5. Ecological Diversification and Insect Diversification and Specialization 243

5.1 Ecological Diversification and Plant Specialization 243

$\begin{array}{ll}5.2 \text { Reproductive Isolation and Speciation } & 245\end{array}$

5.3 Evolutionary Dynamics of Plant-Insect-Microbe Interactions 246

6. Conclusion and Outlook 247

Acknowledgements $\quad 249$

$\begin{array}{ll}\text { References } & 249\end{array}$ 


\section{Abstract}

There is growing evidence that microorganisms are important 'hidden players' in insect-plant interactions. Insect symbionts can directly affect these interactions by providing insects with key nutrients or by interfering with the plant to modulate food provisioning to insects and plant defences. Insect symbionts can also have indirect cascading ecological consequences at the community level through insect- and plantmediated effects that include their impact on insect reproduction, on natural enemies of herbivores or on plant-associated microorganisms. Identification of symbiotic communities associated with insects, characterization of transmission and acquisition patterns as well as understanding of molecular mechanisms underlying these plantinsect-microbe interactions have important ecological and evolutionary consequences. This review highlights the excitement that surrounds these investigations and the promise they hold for a better understanding of the functional, ecological and evolutionary impacts of symbionts on plant-insect interactions, with implications and relevance for both applied and fundamental researches.

\section{INTRODUCTION}

Nutrition is the cornerstone of most interactions between organisms. With more than 4 million estimated species, insects are among the most significant evolutionary successes on Earth (Novotny et al., 2002). The origin of this success can be directly linked to the diversity of their feeding strategies, of which herbivory is the most common (Schoonhoven, van Loon, \& Dicke, 2005; Slansky \& Rodriguez, 1987). However, plant tissues are typically suboptimal nutritionally, due to unbalanced ratios and/or low levels of key nutrients and frequent requirement to detoxify plant-defensive allelochemicals (Schoonhoven et al., 2005). The ability of phytophagous arthropods to exploit plant resources requires them to employ a suite of pre- and postingestive mechanisms to address the nutritional mismatch between what plants provide and what insects require (Raubenheimer, Simpson, \& Mayntz, 2009). These strategies include specific behavioural and physiological adaptations (Behmer, 2009), intricate interactions that involve insect reprogramming of host plant development (Giron, Huguet, Stone, \& Body, 2016; see also chapter: From Plant Exploitation to Mutualism by Lieutier et al., 2017), symbioses in which plants have evolved food rewards specifically for insects (e.g., Heil \& McKey, 2003) and also associations with one or more symbiotic partners (Sugio, Dubreuil, Giron, \& Simon, 2015).

Microorganisms have been shown to be important 'hidden players' in insect-plant interactions (Biere \& Bennett, 2013; Frago, Dicke, \& Godfray, 2012; Sugio et al., 2015) and can affect, among other traits, insect host plant range (Chu, Spencer, Curzi, Zavala, \& Seufferheld, 2013; Hosokawa, Kikuchi, Shimada, \& Fukatsu, 2007), feeding efficiency of the insect (Brune \& Dietrich, 2015), insect metabolism (Douglas, 2013), ability of the insect to 
manipulate the plant physiology for their own benefit (Giron et al., 2016; Kaiser, Huguet, Casas, Commin, \& Giron, 2010) and more generally insect diversification and speciation (Vavre \& Kremer, 2014). Insect symbionts can indeed directly or indirectly affect the plant by interfering with plant signal transduction pathways, repressing or counteracting the expression of plant defence-related genes or altering plant primary and secondary metabolisms (Body, Kaiser, Dubreuil, Casas, \& Giron, 2013; Giron, Frago, Glevarec, Pieterse, \& Dicke, 2013; Sugio et al., 2015; Zhu, Poelman, \& Dicke, 2014). Insect symbionts can also affect plant-insect interactions through their direct or indirect effects on their insect host by providing new metabolic pathways (Douglas, 2013; Moran, McCutcheon, \& Nakabachi, 2008) and/or by altering insect reproduction (Engelstädter \& Hurst, 2009; Ferrari \& Vavre, 2011) or insect immunity with consequences on plant exploitation (Dubreuil, Deleury, Crochard, Simon, \& Coustau, 2014). Finally, they can also modulate insect interactions with natural enemies or plant-associated organisms such as other herbivores, plant symbionts or plant pathogens (Biere \& Bennett, 2013; Chuche, Danet, Salar, Foissac, \& Thiéry, 2016; Frago et al., 2012; Sugio et al., 2015).

This chapter focuses on recent studies on symbionts associated with herbivorous insects that directly or indirectly influence insect-plant interactions. Although plant-associated symbionts are another important and active research field, it is not addressed here. This chapter details (1) the diversity of microbial communities and the ecological dynamics of insect host-microbe interactions, (2) the direct and (3) indirect effects of symbionts on plant-insect interactions, and (4) the roles symbionts may play on insect diversification and specialization on host plants. This review more particularly aims at highlighting the excitement that surrounds investigations on plant-insect-symbionts interactions and the promise they hold for a global understanding of plant-insect interactions.

\section{DIVERSITY OF INSECT MICROBIAL COMMUNITIES AND ECOLOGICAL DYNAMICS OF INSECT HOST- MICROBE INTERACTIONS}

\subsection{Diversity of the Symbionts Associated With Herbivorous Insects}

The term 'symbiont' generally refers to microorganisms that live in intimate interaction with a host permanently or at least during a substantial part of the host's life cycle. Symbiotic associations are extremely diverse in herbivorous insects not only due to the taxonomic diversity of the microbial 
partners engaged (i.e., fungi, protists, bacteria, archae or viruses) but also due to other attributes such as: (1) the location of the symbionts relative to the host body, (2) the transmission mode of the symbionts through host generations, (3) the number of distinct microbial taxa coexisting within host individuals, (4) the nature of the host-symbiont interactions along the parasitism-mutualism continuum or (5) the degree of dependence between symbiotic partners for survival and reproduction. Symbionts associated with herbivorous insects can therefore be classified in many ways. However, the location of the symbionts is a relevant categorization criterion to characterize symbionts that possibly influence insect-plant interactions. The location of the symbionts in insect tissues may indeed restrict the nature and intensity of actions on host plants (Hansen \& Moran, 2014).

Many herbivorous insects harbour intracellular symbionts that are inherited maternally through the germ line. The most studied intracellular symbionts are undoubtedly bacteria living in specialized host cells (i.e., bacteriocytes) that are required for the host's nutrition and survival (Baumann, 2005). Such obligate symbionts, also called 'primary symbionts', have been described in a variety of herbivorous insect taxa, although they have been particularly well studied in sap-feeding hemipterans in which they complement the unbalanced diet (i.e., phloem, xylem) of their hosts by providing nitrogen, essential amino acids and vitamins (Moran et al., 2008). Recent studies revealed that intracellular symbionts also include a variety of bacteria that are facultative for host survival and reproduction. These 'secondary symbionts' can nevertheless deeply influence their hosts' biology and ecology in a variety of ways along the parasitism-mutualism continuum. Some secondary symbionts such as Wolbachia impact host reproduction by inducing various phenotypic effects (Engelstädter \& Hurst, 2009). However, intracellular secondary symbionts can also have beneficial effects for their hosts, conferring protection to natural enemies (Oliver, Smith, \& Russell, 2014; see also Section 4.2) or mediating interactions between their hosts and the plants they consume (Kaiser et al., 2010; see also Sections 3.3 and 3.4). They can act in conjunction with primary symbionts and even replace them (see Sections 3.1 and 3.4).

Herbivorous insects, as most other animals, also harbour microorganisms in their intestinal tracts. Most of these gut microorganisms are bacteria, but insects feeding on wood or plant litter can also harbour fungi, protists or methanogenic archaea (Brune \& Dietrich, 2015). The diversity and composition of gut microbial communities strongly vary among insects from very simple to highly complex microbial assemblages composed by hundreds of 
taxa representative of the three domains of life (i.e., bacteria, archaea and eukaryotic microbes) (Engel \& Moran, 2013). Recent investigations also support the general view that both diet and evolutionary history of the hosts shape gut communities (Colman, Toolson, \& Takacs-Vesbach, 2012; Jones, Sanchez, \& Fierer, 2013). The consequences of intestinal symbionts in insects have been relatively less investigated than those induced by intracellular symbionts. Nevertheless, it has become clear that gut symbionts can have beneficial effects on their hosts, contributing, for example, to nutrition, protection from parasites and pathogens, modulation of immune responses and communication (Engel \& Moran, 2013; Lizé, McKay, \& Lewis, 2013).

Some insects have domesticated external symbionts, mostly fungi, which live outside their body (Aylward et al., 2014). The most studied ectosymbionts are known to help their hosts to feed directly or indirectly on fresh or decaying plant materials. Fungus-farming ants and termites cultivate these symbionts in their nests (Mueller, Gerardo, Aanen, Six, \& Schultz, 2005; Poulsen et al., 2014), while ambrosia beetles cultivate them in their galleries (Kostovcik et al., 2015). In other cases, such as stink bugs, symbionts can be acquired by feeding on a capsule deposited by the mothers nearby their eggs (Hosokawa, Kikuchi, Meng, \& Fukatsu, 2005) or directly from the soil at every generation (Kikuchi, Hosokawa, \& Fukatsu, 2007). In these mutualistic associations, the symbionts contribute to the nutrition of their hosts, whereas the symbionts benefit from the association for food provisioning and dispersion. It is likely that ectosymbionts are much more common in herbivorous insects than described so far and provide benefits not only for nutrition but also possibly for modulating host plant recognition or detoxifying secondary plant compounds (Hansen \& Moran, 2014).

\subsection{Characterization of Microbial Diversity in Insects: Identification and Localization}

Because most symbionts cannot be cultivated outside their hosts, characterization and identification of microbes associated with insects rely primarily on molecular techniques. Before the development of next-generation sequencing technologies, assessment of symbiont diversity and composition was mainly achieved by cloning and sequencing $16 \mathrm{~S}$ or $18 \mathrm{~S}$ rRNA partial or complete genes for prokaryotes and eukaryotes, respectively. These genomic regions generally contain sufficient molecular variations to discriminate microbial taxa and to infer symbiont species from DNA sequences. Specific primers can then be designed to selectively amplify the symbiont(s) of interest in order to study, for example, the prevalence and transmission 
patterns of associated microbes. Multilocus sequence typing is also a widespread technique to discriminate between strains of microbes that can infect the same or different insect hosts (e.g., Henry et al., 2013).

In addition to qualitative data, these specific primers can be used to measure the abundance of symbionts within the host by quantitative polymerase chain reaction. Metagenomic, genomic and transcriptomic data obtained by high-throughput sequencing is now replacing classical polymerase chain reaction amplification and cloning techniques to detect microbial partners. These genomic data sets are then processed with adapted bioinformatics tools allowing to identify the full diversity of microbial communities associated with insects (i.e., the microbiome) and to tackle the way the microbiota influence the host's phenotype. Complete genomes of insect symbionts are now available for many systems and have been decisive to elucidate evolutionary patterns of insect symbiosis and to reveal symbiotic functions through metabolic networks inference.

Besides the characterization of symbiont diversity and functions, localizing microbes inside their hosts is also important to understand host-symbiont or symbiont-symbiont interactions as well as transmission patterns of the symbionts. Fluorescence in situ hybridization method is generally employed to visualize symbionts and symbiotic organs inside the host. Transmission electron microscopic observations allow a much deeper analysis of symbiont ultrastructure and can allow to distinguish between different symbiont taxa inhabiting the same host tissue by using specific immunegold labelling (Tsuchida, Koga, Fujiwara, \& Fukatsu, 2014).

\subsection{Symbiont Transmission and Acquisition at the Inter- generational Level}

Symbiont transmission maintains symbiotic associations through host generations and represents a pivotal factor in their evolutionary stability and diversification (Salem, Florez, Gerardo, \& Kaltenpoth, 2015). Although the transmission mechanisms are diverse, three principal modes of symbiont transmission can be distinguished: vertical, horizontal and mixed.

In herbivorous insects, most vertically transmitted symbionts are transferred from the mother to the offspring (maternal inheritance). This is the case in the widespread intracellular symbionts, which are, in host females, translocated from bacteriocytes to the germ line where they are internalized in maturing oocytes. Maternal inheritance is nevertheless not restricted to intracellular symbionts and it also occurs in intestinal and external symbioses (Salem et al., 2015). In the European firebug, for instance, the transmission 
of beneficial gut symbionts relies on secretions that are smeared over the egg surface following oviposition (Kaltenpoth, Winter, \& Kleinhammer, 2009). It is worth noting that, in rare instances, the transmission of symbionts to the offspring is ensured by both parents (bi-parental inheritance). For example, the gut symbionts of termites are transferred from the royal couple founding a new colony to their first hatched larvae, which lick and ingurgitate symbiont-rich fluids excreted by their parents (i.e., proctodeal trophallaxis) (Brune \& Dietrich, 2015).

Horizontally transmitted symbionts can be acquired by the hosts either from conspecific or hetero-specific host individuals, or directly from the environment. In the former situation, coprophagy might play a major role in some bugs, cockroaches and termites (Salem et al., 2015). In these cases, symbiont acquisition by symbiont-free individuals requires direct contact with faeces after excretion. In other insects such as in the bean bug, Riptortus pedestris (Fabricius, 1775) (Hemiptera: Coreoidea), laboratory studies revealed that some beneficial gut symbionts are acquired directly from the environment (Kikuchi et al., 2007).

In many instances, symbionts can be transmitted both vertically and horizontally. Many facultative maternally transmitted intracellular symbionts such as Wolbachia are known to be occasionally transferred between unrelated insect species through a range of mechanisms (Koehncke, Telschow, \& Kondoh, 2012). An interesting example is the intracellular Rickettsia bacteria infecting the whitefly, Bemisia tabaci (Gennadius, 1889) (Hemiptera: Aleyrodidae). Whereas this facultative symbiont is primarily transmitted maternally via the eggs, the bacteria can also be transferred among $B$. tabaci host lineages via the host plant, the symbiont being found in the phloem of several plant species following feeding by an infected whitefly (Caspi-Fluger et al., 2012).

\section{DIRECT EFFECTS OF SYMBIONTS IN PLANT-INSECT INTERACTIONS}

\subsection{Influence on Insect Nutrition and Metabolism}

Most insects that feed exclusively on unbalanced diet such as plant sap have developed symbiosis with microorganisms that provide essential amino acids and vitamins that are present in short supply in their food and that insects cannot synthetize on their own (Baumann, 2005; Buchner, 1965). These obligate symbioses have been keys in the ability of some insects to 
colonize new ecological niches. Most often these interactions involve intracellular bacteria that are maternally inherited and located in dedicated organs. The most documented example is probably the association between Buchnera aphidicola and aphids (Buchner, 1965), but association between Sulcia and Auchenorrhyncha (a sap-feeding insect group including plant hoppers, cicadas, spittlebugs, leafhoppers - Cryan \& Urban, 2012) is the oldest symbiosis reported in insects $(\sim 270$ millions of years; Moran, Degnan, Santos, Dunbar, \& Ochman, 2005). Usually, all nutrient biosynthetic pathways are present and complete in these obligate symbionts despite extremely reduced genomes (Moran et al., 2008). However, some of them have lost some key metabolic genes, involved in the production of essential amino acids, for example, relying on the host and/or another symbiont to compensate for the loss of essential metabolic traits by the obligatory symbiont. For example, Sulcia muelleri, the obligate symbiont of sharpshooters and other Auchenorrhyncha, can produce 8 out of the 10 essential amino acids, the 2 missing amino acids being provided by partnering symbionts, Baumannia cicadellinicola and Hodgkinia cicadicola, respectively (McCutcheon, McDonald, \& Moran, 2009). Metabolic interdependency can also occur when obligatory symbionts have incomplete biosynthetic pathways. The primary symbiont Portiera aleyrodidarum of the whitefly B. tabaci has lost three genes involved in lysine synthesis which are present in the genome of the common facultative symbiont Hamiltonella defensa (Rao et al., 2015; Rollat-Farnier et al., 2015). In this intricate interaction, the genome of $B$. tabaci also contributes to multiple metabolic reactions through genes of insect origin but also thanks to other genes that were horizontally acquired from other bacteria (Luan et al., 2015).

\subsection{Influence on Insect Immunity and Plant Exploitation}

The invertebrate's innate immune system was reported to show some forms of adaptive features including highly diversified recognition systems, complex regulatory processes and specific effectors (e.g., Baeza Garcia et al., 2010; Hoffmann \& Reichhart, 2002; Schulenburg, Boehnisch, \& Michiels, 2007). In aphids, adaptation to feeding on phloem is largely ensured by their association with Buchnera. Aphids also interact with bacterial secondary endosymbionts that are facultative (Oliver, Degnan, Burke, \& Moran, 2010) and can influence the immune response of their insect hosts (Laughton, Fan, \& Gerardo, 2014; Schmitz et al., 2012). In pea aphids, a negative effect of symbionts on expression of immune gene members of the macrophage migration inhibitory factor (MIF) family was reported 
(Dubreuil et al., 2014). MIFs are known as important pro-inflammatory cytokines regulating immune responses of vertebrates (Calandra \& Roger, 2003). The presence of facultative symbionts correlated with a decreased expression of the MIF genes in aphids and an increased expression of MIF genes was observed in aphids without secondary symbionts after injection with the gram-negative bacteria Escherichia coli. Additionally, among the five members of MIF multigene family, ApMIF1 is the unique member encoding MIF protein that is secreted during aphid feeding (Naessens et al., 2015). The RNA interference targeting the ApMIF1 resulted in a significant decrease in aphid success in phloem feeding and functional analysis showed that MIF interferes with the plant immune system, suggesting that MIF secretion mimics or antagonizes plant proteins to repress plant immune responses. Presence of symbionts could thus modulate the ability of the pea aphid to exploit its host possibly by repressing the plant immune response.

\subsection{Influence on Plant Nutritional Status and Morphology}

Phytohormones lay at the very core of molecular mechanisms controlling plant growth, defence and/or nutritional status (Erb, Meldau, \& Howe, 2012; Giron et al., 2013). The ability to control the plant phytohormonal balance is a well-characterized mechanism used by several plant-associated microorganisms to colonize and exploit the plant (Giron \& Glevarec, 2014). Indeed, plant-associated microorganisms potentially influence the levels of phytohormones by inducing plant genes involved in phytohormone biosynthesis, metabolism, degradation or response, but they can also produce and secrete relevant phytohormones themselves (Giron et al., 2013). There is also growing evidence that insect-associated microbes are active players in plant manipulation to the benefit of the insect host (Body et al., 2013; Kaiser et al., 2010; Sugio et al., 2015).

Curing the apple tree leaf-miner, Phyllonorycter blancardella (Fabricius, 1781) (Lepidoptera: Gracillariidae) of its endosymbiotic Wolbachia bacteria resulted in the loss of the cytokinin (CK)-induced green-island phenotype on apple tree leaves and in the absence of detectable CKs in larvae compared to nontreated controls (Body et al., 2013; Kaiser et al., 2010). These results suggest that these insects have the ability to modify the phytohormonal profile in mined leaf tissues and to deliver CKs to the plant via their association with symbiotic bacteria (Giron \& Glevarec, 2014; Zhang et al., 2016). This allows insects to 'hijack' plant metabolism, thus enabling them to successfully invade the plant by inhibiting plant defences and withdrawing plant 
resources for their own benefit (Zhang et al., 2016). The first survey of bacteria associated with the gut of a plant-manipulating insect, the Hessian fly, has recently revealed a predominance of Pseudomonas species (Bansal et al., 2014), the genomes of which were identified in whole-genome sequencing of the Hessian fly, Mayetiola destructor (Say, 1817) (Diptera: Cecidomyiidae) (Zhao et al., 2015). It remains to be seen whether these bacteria, or other microbes associated with the insect, modify host plant nutrition and development, leading to gall induction.

Besides bacteria, other symbionts may also help insects to manipulate their host plant. Some gall midges have a symbiotic association with biotrophic fungi that are essential for invasion of plant stems and access to vascular tissue, for providing larvae with highly nutritious food and for gall development (Rohfritsch, 2008). The molecular mechanisms underlying such tripartite interactions involving fungi still need to be uncovered. Cornell (1983) suggested that viruses or viral proteins could be involved in the delivery of stimuli in gall-inducing cynipids.

\subsection{Impact on Plant Secondary Metabolism/Plant Immunity}

Insect symbionts can also be involved in the suppression of phytohormonemediated plant defence signalling (Giron et al., 2013, 2016; Sugio et al., 2015). A striking example is the Colorado potato beetle, Leptinotarsa decemlineata (Say, 1824) (Coleoptera: Chrysomelidae), that releases bacteria in its oral secretions, resulting in the activation of a plant microbial defence response through the induction of the salicylic acid-signalling pathway. This leads in turn, by negative cross-talk, to downregulation of the jasmonic acid (JA)-responsive antiherbivore resulting in improved larval growth (Chung et al., 2013). These results show that the herbivore disrupts plant perception and evades antiherbivore defences by exploiting symbiotic bacteria. However, symbionts do not always benefit their host as shown in the aphid-Buchnera system, where a symbiont protein delivered in the insect saliva is recognized by the plant and elicits reaction defences (Chaudhary, Atamiana, Shenc, Briggsc, \& Kaloshian, 2014).

Plant defence suppression involving insect-associated bacteria was also suggested in the maize-corn rootworm [Diabrotica virgifera virgifera (Le Conte, 1868) (Coleoptera: Chrysomelidae)] interaction, in which Wolbachia infection was positively correlated with the ability of the larvae to inhibit defence gene expression in the maize (Barr, Hearne, Briesacher, Clark, \& Davis, 2010). However, further work showed that endosymbiont-free insects do not elicit different maize defence responses in comparison to 
Wolbachia-infected insects (Robert et al., 2013), suggesting that symbiont effects can be context dependent.

In the whitefly $B$. tabaci, saliva of individuals harbouring the facultative symbiont $H$. defensa is able to suppress JA-related defences in tomato compared to saliva from noninfected controls (Su et al., 2015). Putative non-proteinaceous effectors were identified in the saliva, but it remains to know their origin and exactly how $H$. defensa mediates the suppression of plant defences in this system. $H$. defensa also serves as a nutrient provider in whiteflies (Luan et al., 2015; Rao et al., 2015; Rollat-Farnier et al., 2015; see Section 3.1), illustrating the multiple ways in which a symbiont can impact overall insect fitness. Feeding by the silverleaf whitefly has been shown to induce SA defences and to suppress JA responses in Arabidopsis (Zarate, Kempema, \& Walling, 2007). Whether this ability is endogenous to the insect or is symbiont-associated awaits validation. Recently, leafmining larvae of Scaptomyza flava (Fallén, 1823) (Diptera: Drosophilidae) have been shown to vector Pseudomonas syringae bacteria to and from feeding sites and that the larvae perform better on plants infected with $P$. syringae. Here, the suggested mechanism is that $P$. syringae acts by suppressing antiherbivore defences mediated by reactive oxygen species (Groen et al., 2016).

Rather than interfering with plant defence signalling, insect symbionts can also inhibit or counteract plant defences as suggested in the cigarette beetles (Dowd \& Shen, 2011) and in the gypsy moth (Broderick, Raffa, Goodman, \& Handelsman, 2004). This could be achieved through the direct or indirect production of enzymes targeting plant-defensive compounds. The microbial community of the mountain pine beetle, Dendroctonus ponderosae (Hopkins, 1902) (Coleoptera: Curculionoidea), seems to contribute to overcome the plant's terpenoid-based defences by degrading them (Boone et al., 2013). Dendroctonus ponderosae is strongly associated with microbial communities that are enriched with genes involved in terpene degradation compared with other plant biomass-processing microbial communities (Adams et al., 2013). Furthermore, the bacteria associated with $D$. ponderosae were shown to metabolize monoterpenes and diterpene acids that are toxic to beetles (Boone et al., 2013). Similarly, gut bacteria isolated from the velvet bean caterpillar, Anticarsia gemmatalis (Hübner, 1818) (Lepidoptera: Noctuidae), a soybean pest, are involved in serine proteinase production. Higher production of proteases induced or produced by the bacteria might contribute to the adaptation of the caterpillar to the soybean plant, which is rich in protease inhibitors (Visotto, Oliveira, 
Guedes, Ribon, \& Good-God, 2009). A comparison of gut bacterial microbiota of two different variants of $D$. virgifera virgifera showed that the gut bacterial communities of 'rotation-resistant' populations were different from those of wild-type populations. The 'rotation-resistant' variant microbiota contributes to the proteolysis and survival of $D$. virgifera virgifera on nonhost soybeans, suggesting that this adaptation of the western corn rootworm to a new host plant is directly linked with a modification of the gut bacteria adapted to tolerate the antiherbivory defences expressed in soybean foliage (Chu et al., 2013).

\subsection{Genes Acquired by Horizontal Gene Transfer That Influence Plant-Insect Interactions}

Mechanisms and actual microbial genes involved in symbionts-associated interference with plant defence signalling and plant physiological status still await characterization. Candidate microbial genes most likely playing important roles in plant-herbivore interactions, have however been identified within genomes of insect pests following acquisition via horizontal gene transfer (HGT) events (Boto, 2014). Indeed, there is increasing evidence that HGTs (i.e., transmission of genetic material between organisms other than by descent) play a role in eukaryotic evolution leading to acquisition of novel traits (Boto, 2014; Soucy, Huang, \& Gogarten, 2015). Several examples of HGT described in insects concern microbial genes involved in the adaptation of insects to plants, either because these genes encode specific enzymes allowing degradation and metabolism of plant products or because they may enable detoxification of potentially harmful plant components.

Several studies have reported the presence of genes encoding Plant Cell Wall Degrading Enzymes in different herbivorous insects. Some of these genes are likely endogenous insect genes (Calderon-Cortes, Quesada, Watanabe, Cano-Camacho, \& Oyama, 2012), while others most likely derived from HGTs from different microbial sources (Kirsch et al., 2014). These horizontally acquired genes related to plant feeding have been particularly well investigated in beetles and weevils (e.g., Acuña et al., 2012; Kirsch, Heckel, \& Pauchet, 2016). For example, the coffee berry beetle harbours in its genome a functional mannanase gene, phylogenetically related to Bacillus genes, that is presumed to facilitate feeding within the coffee berry by hydrolyzing galactomannan, the major storage polysaccharide in this plant (Acuña et al., 2012). Studies combining 
molecular evolution and enzymatic assays show that many of these genes have undergone duplication and diversification events since their acquisition suggesting their important role in beetle adaptation to plants (Kirsch et al., 2016). Similarly, evidence for multiple HGT of genes involved in sugar and amino acid metabolism followed by duplications and diversification were reported in lepidopteran genomes (Sun et al., 2003) and 30 candidate HGT events involving mainly carbohydrate metabolic enzymes in Hessian fly (Zhao et al., 2015) suggest that the acquisition of these genes could be recurrent in herbivorous insect species, allowing better utilization of plant carbohydrates by these insects.

Acquisition of genes by phytophagous insects via horizontal transfer from microorganisms could also be involved in detoxification of plant products. A gene of bacterial origin encoding $\beta$-cyanoalanine synthase was shown to allow mites and Lepidoptera to feed on plants releasing toxic hydrogen cyanide upon tissue disruption (Wybouw et al., 2014). In the silkworm, $\beta$-fructofuranosidase genes of probable bacterial origin have been proposed to play a critical role in this caterpillar's ability to avoid the toxic effects of sugar mimic alkaloids present in mulberry latex, that are highly toxic to nonmulberry specialist insects (Daimon et al., 2008). In the same vein, carotenoid biosynthesis genes of fungal origin have been identified in different herbivorous arthropods (Cobbs, Heath, Stireman, \& Abbot, 2013; Grbić et al., 2011; Moran \& Jarvik, 2010) and have been suggested to contribute to the herbivorous lifestyle by playing a role as antioxidants (Cobbs et al., 2013). Finally, in hemipteran species known to host obligate endosymbiotic bacteria, HGT events could be identified in the insect genomes that correspond to genes phylogenetically distinct from those of the endosymbionts and that facilitate the mutualistic associations. These HGT genes contribute to the association with the host plant by facilitating the nutritional symbiosis (Luan et al., 2015; Nikoh et al., 2010).

The fact that HGT events have been identified in several other plant parasite species, such as mites and nematodes, suggests that the acquisition of genes by HGT may play an important role in transitions to plant parasitic lifestyles or to herbivory on specific host plants or tissues (Grbić et al., 2011). It is predictable that growing genomic data on insects will unveil new evidence of HGT. Furthermore, new functional approaches allowing targeted inactivation of genes may help to formally link the acquisition of these genes with insect adaptive traits. 


\section{INDIRECT EFFECT OF SYMBIONTS IN PLANT- INSECT INTERACTIONS: INSECT- AND PLANT- MEDIATED INDIRECT EFFECTS}

\subsection{Impact on Insect Reproduction}

One strategy employed by symbionts to maintain and invade insect populations is the induction of reproductive manipulations, which have been most extensively studied in the case of vertically transmitted endosymbionts. Indeed, this uniparental transmission favours strategies that increase daughter production at the expense of son production. These effects include the feminization of genetic males, the induction of thelytokous parthenogenesis, the killing of infected sons and the induction of cytoplasmic incompatibility (CI), a form of postzygotic reproductive sterility occurring when infected males mate with uninfected females or females infected with another strain of the symbiont (Werren, Baldo, \& Clark, 2008). While the most famous reproductive manipulator is the bacterium Wolbachia, other symbionts, such as Arsenophonus, Cardinium, Rickettsia or Spiroplasma, are also able to manipulate their host reproduction (Engelstädter \& Hurst, 2009). These symbionts infect a large number of insect species (see, for example, Duron et al., 2008). Interestingly, relatively few cases of reproductive manipulation by symbionts have been described in Hemiptera. In aphids, one potential reason for this is that many species exhibit complete or cyclical parthenogenesis, which may impair the efficiency of reproductive manipulation. Simon et al. (2011) however demonstrated that Spiroplasma induces male killing in the pea aphid. Male-killing bacteria can be maintained in their host populations when killing males procure an indirect advantage to infected females either through the limitation of competition with their brothers or through avoidance of inbreeding depression. This latter point makes a lot of sense in the case of the pea aphid that exhibits cyclical parthenogenesis with maintenance of the genotypic composition during subsequent clonal generations. Indeed, if inbreeding depression is important, limitation of inbreeding due to male killing during the annual event of sexual reproduction may provide an advantage not only at that moment but also during subsequent clonal generations, thus benefiting to the females harbouring the male killer all along the year. This hypothesis would be worth testing either theoretically or by field surveys. Alternatively, Spiroplasma may provide other benefits to its hosts that would explain its maintenance in pea aphid populations (Eukasik, van Asch, Guo, Ferrari, \& Godfray, 2013). In whiteflies, the recent invasion of Rickettsia in the 
United States has also been associated with increased female bias in the progeny of infected females (Himler et al., 2011), which may in turn affect the population dynamics of whiteflies.

While not directly influencing the insect-plant interactions, reproductive manipulators can modulate the population dynamics (either positively or negatively) and tend to reduce the genetic diversity and/or recombination rates in infected species (Engelstädter \& Hurst, 2009). Through cascading effects, this may ultimately impact the functioning of ecological networks and their co-evolutionary dynamics (Ferrari \& Vavre, 2011). These effects could impact not only plant-insect interactions, preypredator or host-parasitoid interactions but also competitive interactions at a given trophic level (e.g., between herbivores). As an example, the virus LbFv, which manipulates the reproductive behaviour of the parasitoid Leptopilina boulardi (Barbotin \& Carton et Keiner-Pillault, 1979) (Hymenoptera: Eucoilidae) decreases the competitive ability of this species against Leptopilina heterotoma (Thomson, 1862) (Patot, Allemand, Fleury, \& Varaldi, 2012). Importantly, the effects of reproductive manipulators on ecological networks, and notably on insect-plant interactions, remain mostly unstudied despite their potential importance.

Reproductive manipulators may also provide interesting candidate for the development of alternative control strategies. In particular, CI-inducing Wolbachia could be used to develop insect incompatible techniques (IITs). The proof of principle has been obtained in the fruit fly Ceratitis capitata (Wiedemann, 1824) (Diptera: Tephritidae) (Zabalou et al., 2004). This species is naturally not infected by any reproductive manipulator. Through artificial transfection, a Wolbachia strain from Rhagoletis cerasi (Linnaeus, 1758) has been introduced in C. capitata, where it induces 100\% CI. Population cage experiments have shown that releasing infected males can indeed be used to control the host populations, in a way very similar to the sterile insect techniques (SIT). One advantage of IIT over SIT is that infected males are generally much more competitive than irradiated males. One drawback is however that only males should be released, which requires perfect sexing strategies, even though alternative strategies have recently been proposed that combine IIT and SIT (Bourtzis, Lees, Hendrichs, \& Vreysen, 2016).

\subsection{Interactions With Natural Enemies of Herbivores: Protection Versus Attraction}

For their maintenance in host populations, some heritable facultative symbionts have adopted strategies that have direct beneficial effects on host 
fitness. These effects include host plant adaptation (Tsuchida, Koga, \& Fukatsu, 2004) and resistance to adverse abiotic (i.e., heat tolerance, Montllor, Maxmen, \& Purcell, 2002) but also biotic stresses (Oliver et al., 2010). Microbial symbionts have become increasingly recognized to mediate interactions between herbivorous insects and their natural enemies and, as such, they are important players in the effectiveness of natural enemies to regulate herbivore populations. In herbivorous insect species, symbiont-mediated protection has been first demonstrated in aphids and subsequently observed in other host species such as Drosophila spp. Many more examples of protective symbioses in insects will surely be discovered (Oliver et al., 2014). These protective phenotypes may of course impact directly the population dynamics of the host insect, but can also greatly affect the entire community of phytophagous insects through cascading effects (Sanders et al., 2016).

In aphids, facultative bacterial symbionts confer protection against various natural enemies. Different strains of $H$. defensa have been shown to protect the pea aphid Acyrthosiphon pisum (Harris, 1776) (Hemiptera: Aphididae), the black bean aphid Aphis fabae (Scopoli, 1763) and the cowpea aphid Aphis craccivora (Koch, 1854) against insect parasitoids (Asplen et al., 2014; Oliver, Russell, Moran, \& Hunter, 2003; Schmid, Sieber, Zimmermann, \& Vorburger, 2012). Hamiltonella defensa would protect against a large range of parasitoid species in $A$. pisum, although this facultative symbiont may not protect all its host aphid species [e.g., the grain aphid Sitobion avenae (Fabricius, 1775), Łukasik, Dawid, Ferrari, \& Godfray, 2013]. Protection of aphids against parasitoids could also be associated with other bacterial symbionts: Regiella insecticola in the green peach aphid, Myzus (Nectarosiphon) persicae (Sulzer, 1776) (Vorburger, Gehrer, \& Rodriguez, 2010) and both Serratia symbiotica and the Pea Aphid X-type Symbiont in the pea aphid (Guay, Boudreault, Michaud, \& Cloutier, 2009; Oliver et al., 2003). Symbionts can also protect aphids against predators and pathogens: Rickettsiella viridis provides protection of the pea aphid against ladybirds (Polin, Gallic, Simon, Tsuchida, \& Outreman, 2015) and this aphid species may also be protected against fungal pathogens when infected with $R$. insecticola, R. viridis or Spiroplasma (Ferrari, Darby, Daniell, Godfray, \& Douglas, 2004; Łukasik, van Asch, et al., 2013). As protection against natural enemies can be favoured by natural selection, protective symbionts are expected to be fixed within natural aphid populations. Interestingly, these symbionts are found at 
intermediate frequencies within populations, suggesting that some forces limit their prevalence such as infection costs (Simon et al., 2011).

In Drosophila, examples of symbiont-mediated protection are accumulating, and two lineages of bacteria that infect the genus are known to be protective: Wolbachia and Spiroplasma. Xie, Vilchez, and Mateos (2010) showed that Spiroplasma enhances larva-to-adult survival of the fruit fly Drosophila hydei (Sturtevant, 1921) (Diptera: Drosophilidae) when parasitized by L. heterotoma parasitoid, which attacks the larvae of many Drosophila spp. Wolbachia has been shown to defend the fruit flies Drosophila melanogaster (Meigen, 1830), Drosophila simulans (Sturtevant, 1919), Drosophila innubila (Spencer, 1943) and Drosophila suzukii (Matsumura, 1931) against multiple RNA viruses (e.g., Cattel, Martinez, Jiggins, Mouton, \& Gibert, 2016; Hedges, Brownlie, O’Neill, \& Johnson, 2008). So far, Wolbachia are not known to defend Drosophila against other enemies such as parasitoids or predators (Hamilton \& Perlman, 2013).

Parasitoid protection provided by $H$. defensa in the pea aphid is associated with the presence of a bacteriophage (APSE), which encodes toxins responsible for prematurely arresting the development of parasitoid immatures (Degnan \& Moran, 2008). Underlying mechanisms of parasitoid protection in other systems are often unknown and may involve toxins or diverse biologically active compounds produced by symbionts and targeting insects' natural enemies. Microbial symbionts may also confer protection through indirect mechanisms by competing with natural enemies for limited host resources, by priming the herbivore immune system against subsequent infections (Oliver et al., 2014).

Microbial symbionts may also modulate parasitoid attraction through indirect plant-mediated effects. In response to herbivore attack, plants release distinct bouquets of volatile organic compounds (VOCs) that increase the plant's attractiveness to natural enemies of herbivores (Dicke, van Loon, \& Soler, 2009). Given emerging evidences that insect symbionts can modulate the plant signalling pathways (Sections 3.3 and 3.4), it is most likely that volatile emission is influenced by insect-associated symbionts. Alteration of plant VOCs may also be linked to complex interactions with soil-borne microbes such as mycorrhizal fungi also known to influence VOC emissions (Fontana, Reichelt, Hempel, Gershenzon, \& Unsicker, 2009) with possible interference between plant and insect symbionts (Hackett, Karley, \& Bennett, 2013). 


\subsection{Interactions With Plant Pathogens: Influence of Insect Symbionts on Plant Pathogen Transmission}

Many plant pathogens are transmitted by insect vectors through different types of mechanisms. Plant viruses and phytoplasma are by far those pathogens that rely on insect vectors for their transmission. In some conditions, interests of virus and insect vector may be aligned so that mutualistic associations can evolve. This is, for example, the case of some viruses which reduce plant defences upon their insect vectors' attacks, favouring both the transmission rate of the virus and the growth rate of the insect population (e.g., Luan et al., 2013). Viruses can also increase plant quality with regard to their insect vectors, with mutual benefits for the virus-vector association (Belliure, Janssen, Maris, Peters, \& Sabelis, 2005). In other cases, viruses are thought to 'manipulate' their insect vectors' behaviour and physiology in order to favour their acquisition and/or transmission from plant to plant (Ingwell, Eigenbrode, \& Bosque-Pérez, 2012; Stafford, Walker, \& Ullman, 2011; Su et al., 2013). However, the relationships between plant pathogens, insect vectors and host plants should also consider insect symbionts as a fourth player. They can modulate plant-pathogen transmission by influencing directly or indirectly insect-plant-pathogen interactions (Pinheiro, Kliot, Ghanim, \& Cilia, 2015). In hemipterans such as aphids and whiteflies, the circulative transmission of a luteovirus and geminivirus, respectively, was suggested to depend on the presence of a GroEL protein produced by endosymbiotic bacteria associated with these insects (Gottlieb et al., 2010; Hogenhout, van der Wilk, Verbeek, Goldbach, \& van den Heuvel, 1998; Morin et al., 1999). In the whitefly B. tabaci, vectors of tomato yellow leaf curl virus (TYLCV), different biotypes can be distinguished based on their associations with different symbiotic bacteria (Gueguen et al., 2010). In this system, efficient transmission of TYLCV could be correlated with the presence of a specific symbiotic bacterium, $H$. defensa (Gottlieb et al., 2010; Su et al., 2013). However, the molecular mechanisms involved in plant pathogenic virus-bacterial endosymbiont interactions need refining. A study on an aphid-luteovirus barley yellow dwarf virus interaction suggests that GroEL proteins do not co-localize with virus particles in vivo (Bouvaine, Boonham, \& Douglas, 2011). A more recent study showed that Rickettsia, another facultative symbiont of B. tabaci, improves TYLCV acquisition, transmission and retention in the insects with no involvement of GroEL (Kliot, Cilia, Czosnek, \& Ghanim, 2014). These results are in sharp contrast with the protective phenotypes provided by symbionts 
discussed earlier. In addition, infection by the endosymbiont Wolbachia is currently used in mosquitoes to limit transmission of pathogenic viruses such as dengue to humans (Bourtzis et al., 2016). The role of insect symbionts on insect-vectored plant pathogens is a whole research field requiring further investigation. While its potential for application is important, there is a crucial need to determine the circumstances in which positive or negative interactions have to be expected, which probably relies on the direct and indirect costs and benefits associated to co-infections.

\section{ECOLOGICAL DIVERSIFICATION AND INSECT DIVERSIFICATION AND SPECIALIZATION}

\subsection{Ecological Diversification and Plant Specialization}

As described earlier, phytophagous insects have established a wide range of symbiotic associations with an array of microorganisms. These symbionts can bring key innovations to their hosts allowing them to colonize new habitats or to extend their ecological niches. Symbionts play a major role in the adaptation of phytophagous insects to different lifestyles and feeding regimens (Janson, Stireman, Singer, \& Abbot, 2008). Because sap represents an unbalanced diet for insects, being deprived in some essential amino acids and vitamins, the development of bacterial partnerships has been instrumental in the ecological and evolutionary success of sap-feeding insects (Hansen \& Moran, 2014). Each hemipteran group has established an obligate symbiosis with a specific bacterial lineage: Buchnera for aphids, Carsonella for psyllids, Portiera for whiteflies and Tremblaya for mealy bugs. Diversification of host and symbiont associations during the course of evolution (180 My for the aphid and whitefly symbioses, $120 \mathrm{My}$ for the psyllid symbiosis and $40 \mathrm{My}$ for the mealy bug symbiosis, Moran et al., 2008) allowed these hemipterans to exploit virtually all plant species on earth and to generate a substantial amount of biodiversity (e.g., 4000 aphid species, more than 1500 whitefly species, 3000-3500 psyllid species, 7000 coccid species).

Acquisition by insects of facultative symbionts can be also very influential for ecological diversification. While these symbionts are largely maternally inherited, they can be horizontally transferred through occasional jumps within or between host species. These jumps may represent for their hosts an instantaneous acquisition of ecologically important traits (e.g., defences against parasitoids or fungi). Facultative symbionts may thus be viewed as 
a horizontal gene pool that provides the novel host with adaptive traits allowing the exploitation of new habitats and resources or a better success in the current ecological niche (Henry et al., 2013). In addition, a symbiotic association is a dynamic process which could have many types of evolutionary trajectories. For example, the obligate symbiont may be replaced by a facultative symbiont such as in some lineages of weevils (Toju, Tanabe, Notsu, Sota, \& Fukatsu, 2013) or may evolve complementation with one or more other symbionts such as in conifer aphids (Manzano-Marín, Simon, \& Latorre, 2016), whiteflies (Luan et al., 2015; Rao et al., 2015; Rollat-Farnier et al., 2015), leafhoppers (McCutcheon et al., 2009) or mealy bugs (Husnik et al., 2013).

In some instances, microbial partners may play a role in plant specialization of their host insects. This could be revealed indirectly by showing changes in symbiotic composition of host's populations according to plant species or genus. For example, populations of the chestnut curculio, Curculio sikkimensis (Heller, 1927) (Coleoptera: Curculionidae), differ in the prevalence of a range of bacterial symbionts when found on chestnuts or on acorns of wild oaks (Toju \& Fukatsu, 2011). In the hemipteran Phylloxera notabilis (Pergande, 1904), the bacteria Pantoea agglomerans and Serratia marcescens are absent in the host populations feeding on water hickory, whereas they are abundant in insects feeding on pecan (Medina, Nachappa, \& Tamborindeguy, 2011). Associations between aphids and their commonest facultative symbionts were found to be related more by host plant affiliation than by phylogenetic relationships (Henry et al., 2013). However, other factors than plants can influence symbiont composition of host populations. Therefore, experimental studies are required to support evidence for symbiont-mediated plant specialization in insects. Exchange of the symbiont 'Candidatus Ishikawaella capsulata' between two related stink bug species modifies their performances on crop legumes (Hosokawa et al., 2007). Similarly, the facultative symbiont $R$. insecticola was shown to increase fecundity of the aphid A. pisum and Megoura crassicauda (Mordvilko, 1919) specifically on clover (Tsuchida et al., 2004). However, note that these results have been contradicted by other studies (e.g., McLean, van Asch, Ferrari, \& Godfray, 2011). In the polyphagous aphid, A. craccivora, the symbiont Arsenophonus promotes specialization on locust (Robinia pseudoacacia L.) and could expand dietary breath depending on host genotype (Wagner et al., 2015). In the same line, it was demonstrated that B. tabaci performed better on tomato when infected by the facultative symbiont $H$. defensa, the proposed underlying mechanisms being a suppression of induced plant defences by 
the symbiont (Su et al., 2015). The same seems to apply to the olive fly, Bactrocera oleae (Rossi, 1790) (Diptera: Tephritidae), whose gut symbiont Erwinia dacicola enables fly larvae to develop in unripe olives by overcoming plant defences that accumulate during this phenological stage (Ben-Yosef, Pasternak, Jurkevitch, \& Yuval, 2015). In terms of ecological and evolutionary consequences, symbiont mediation of plant specialization may create the conditions for divergent selection among plant-adapted populations or races and eventually trigger speciation events (Wagner et al., 2015).

\subsection{Reproductive Isolation and Speciation}

Symbiosis has been suggested to promote speciation for a long time. However, the microevolutionary mechanisms by which this process could occur were not identified and made this hypothesis too speculative to be truly considered. This idea has however recently resurged (Brucker \& Bordenstein, 2012; Vavre \& Kremer, 2014), which distinguished three processes through which symbiosis could facilitate speciation:

- First, as mentioned in the preceding paragraph, acquisition of new symbionts can lead to the adaptation to new niches through biological innovations. Importantly, when populations are facing contrasted environments, different symbiotic communities may be selected for in response to divergent selection, resulting in the local adaptation of the symbiotic community. Once local adaptation is in place, additional mechanisms are however required to reach speciation. In particular, mechanisms limiting gene flow between populations are required. Interestingly, symbionts have been shown to potentially influence both pre- and postmating isolation.

- Symbiosis could influence premating isolation through different ways. The 'easiest' one is when symbionts are involved in habitat specialization and when mating occurs preferentially in the specialized habitat, such as in aphids, for example, that shows high phylopatry (Peccoud, Ollivier, Plantegenest, \& Simon, 2009). For example, symbiont-mediated specialization of phytophagous insect populations to a new host plant may facilitate reproductive isolation when insect populations reproduce on the plant they are adapted to. Recent results have also provided thought-provoking examples on the ability of symbionts to modify their host behaviour (Lewis \& Lizé, 2015), including modifications involved in premating isolation. These cases involve not only gut symbionts (Lizé, McKay, \& Lewis, 2014; Sharon et al., 2010) but also intracellular bacteria of the genus Wolbachia such as in 
the species complex of Drosophila paulistorum (Miller, Ehrman, \& Schneider, 2010). In this latter case, symbionts could act on both sexes by affecting emission and perception of cues associated with mate choice.

- The effect of symbiosis on postmating isolation has been particularly studied in the case of the Wolbachia-induced CI. When two populations, infected by different strains of mutually incompatible CI-Wolbachia, come into contact, gene flow can be drastically reduced (Bordenstein, O'Hara, \& Werren, 2001). Unidirectional CI can also favour reinforcement process as proposed in Drosophila subquinaria (Spencer, 1942) (Shoemaker, Katju, \& Jaenike, 1999). Other results suggest that symbiosis could also participate to postmating reproductive isolation through more indirect effects. In a few cases, hybrid unviability or sterility has indeed been associated with proliferation of symbionts, notably in D. paulistorum, where symbionts are also involved in prezygotic isolation (Miller et al., 2010). In a similar way, hybrid mortality can be rescued in Nasonia through antibiotic treatments (Brucker \& Bordenstein, 2013). In all these cases, the current hypothesis is that hybrids are not able to control the proliferation of symbiotic bacteria that then turn into pathogens, inducing postzygotic isolation. Reduction in hybrid fitness could thus be due to the rupture of co-adapted gene-symbiont interactions, a specific case of Dobzhansky-Bateson-Muller incompatibilities (Brucker \& Bordenstein, 2012).

All the points mentioned earlier make symbionts potential actors of speciation. Importantly, symbionts, by potentially affecting both ecological specialization and reproductive isolation, may behave act as 'magic traits' promoting ecological speciation (Servedio, Doorn, van Kopp, Frame, \& Nosil, 2011).

\subsection{Evolutionary Dynamics of Plant-Insect-Microbe Interactions}

As already highlighted in previous sections, acquisition of new microbes is a potent mechanism of adaptation for insects. One important question is thus, which are the mechanisms that facilitate or limit the acquisition of symbionts at an ecological and evolutionary time scale? Understanding these mechanisms first requires adopting a community ecology approach of insect-microbe interactions. Indeed, acquisition of a new symbiont first requires that the symbiont comes into contact with the new host species, and this will obviously occur preferentially between species sharing ecological networks (Henry, Maiden, Ferrari, \& Godfray, 2015). For example, in the 
hymenopteran seed feeders of the genus Megastigmus, horizontal transmission of parthenogenesis-inducing Wolbachia has occurred repeatedly, but is constrained by the insect specialization on different plant families (Boivin et al., 2014). Similarly, while different Curculio species developing on oak acorns have distinct predominant symbionts, residual infection by different symbionts probably acquired through recurrent horizontal transmission are observed (Merville et al., 2013). In these examples, horizontal transmission may also be facilitated by the phylogenetic proximity of the hosts, which probably allows better evasion of the host immune system by the symbiont. This phenomenon has also been recently demonstrated using artificial transinfection of symbionts in aphids (Eukasik et al., 2015). However, horizontal transfer between highly divergent species may also occur occasionally (e.g., Vavre, Fleury, Lepetit, Fouillet, \& Bouletreau, 1999). Another factor that may affect the establishment of a new symbiont is the presence of other symbionts.

Interestingly, recent results have demonstrated that some symbionts may be horizontally transmitted in herbivores through interactions with parasitoids (e.g., Rickettsia in whiteflies, Chiel et al., 2009; H. defensa and R. insecticola in aphids, Gehrer \& Vorburger, 2012) or the host plant (e.g., Rickettsia in whiteflies, Caspi-Fluger et al., 2012; or Cardinium in Cicadellidae, Gonella et al., 2015). Importantly, in the case of Rickettsia, the symbiont was apparently metabolically active in the plant, suggesting that at least some symbionts may be able to also exploit the host plant. How these acquisitions may lead to transitions in the lifestyle of symbionts is an open question, but the genus Arsenophonus provides an interesting example of these potential transitions. Indeed, phenotypic effects associated with Arsenophonus are extremely diverse. Known first as a reproductive manipulator, Arsenophonus is also a mutualist in book lice (Perotti, Allen, Reed, \& Braig, 2007), and provision of benefits is also suspected in aphids and whiteflies (Wagner et al., 2015). On the other hand, Arsenophonus is also a plant pathogen vectored by plant hoppers (reviewed in Bressan, 2014). This example highlights the blurred line between insect symbionts and plant pathogens, at least at an evolutionary scale.

\section{CONCLUSION AND OUTLOOK}

In the past few years, insect microbial symbionts have emerged as key players in plant-insect interactions with tremendous ecological and 
evolutionary implications highlighted in this review. They can exert their influence through direct effects on their insect host as well as through indirect plant-mediated effects. Indirect effects can impact the whole plant-associated ecological networks including plant-associated pathogens or mutualistic symbionts but also other herbivores that will exploit the same host plant. One of the forthcoming challenges will be now to connect environment, plant and insect microbiota to shed light on the evolution and functioning of complex multi-trophic interactions in which plants, herbivorous insects and microorganisms are inserted.

As mentioned in this review, higher trophic levels such as parasitoids can also be impacted through direct or indirect interactions with phytophagous insects' symbionts. The rising awareness of the important roles that microbial symbionts play in natural enemies ecology has led to a steep increase in the identification of ecologically important traits being attributed to symbiosis. Because insect microbial symbionts modulate the effectiveness of natural enemies and may be manipulated, they are potential targets for biological control programmes. Qualitative or quantitative alterations of the microbiome may largely modify the ability of insect pests to exploit their host plants but may also improve the ability of parasitoids to detect and control them. Reproductive manipulators may also provide interesting candidates for the development of alternative control strategies by altering the population dynamics of crop pests. Use of symbiotic microorganisms as potential biological agents for controlling insect pests now needs to be fully considered.

Finally, most of the focus has been so far on insect-associated bacteria but other insect symbionts can be instrumental and may help insects to exploit their host plant or to modulate their interactions with their whole ecological community. Extending our knowledge to all types of insect symbionts (e.g., viruses) is now required to gain a deeper understanding of the ecology and evolution of plant-insect interactions. Deciphering molecular mechanisms underlying such plant-insect-microbe interactions in model systems under controlled environments and in more natural ecological settings still also needs to be uncover. The revolution in our understanding of the role of symbionts has been made possible by the many advances in molecular biology. The next decade is likely to see major progress in unravelling the mechanisms underlying these interactions. How microbes associated with insect modify the host plant physiology and development leading to extravagant plant alterations such as galls or how HGT is mediated by plant-insect-microbe interactions and how this promotes the colonization 
of new ecological niches are questions that can now be fully addressed. Understanding mechanisms underlying plant-insect-microbe interactions will shed light on these exciting research topics and hold promise for a global understanding of plant biotic interactions.

\section{ACKNOWLEDGEMENTS}

We are grateful to Akiko Sugio for her constructive comments on an earlier version of this book chapter.

\section{REFERENCES}

Acuña, R., Padilla, B. E., Flórez-Ramos, C. P., Rubio, J. D., Herrera, J. C., Benavides, P., ... Rose, J. K. (2012). Adaptive horizontal transfer of a bacterial gene to an invasive insect pest of coffee. Proceedings of the National Academy of Sciences of the United States of America, 109, 4197-4202.

Adams, A. S., Aylward, F. O., Adams, S. M., Erbilgin, N., Aukema, B. H., Currie, C. R., ... Raffa, K. F. (2013). Mountain pine beetles colonizing historical and naive host trees are associated with a bacterial community highly enriched in genes contributing to terpene metabolism. Applied and Environmental Microbiology, 79, 34683475 .

Asplen, M. K., Bano, N., Brady, C. M., Desneux, N., Hopper, K. R., Malouines, C., ... Heimpel, G. E. (2014). Specialisation of bacterial endosymbionts that protect aphids from parasitoids. Ecological Entomology, 39, 736-739.

Aylward, F. O., Suen, G., Biedermann, P. H., Adams, A. S., Scott, J. J., Malfatti, S. A., ... Klepzig, K. D. (2014). Convergent bacterial microbiotas in the fungal agricultural systems of insects. mBio, 5(6), e02077-14.

Baeza Garcia, A., Pierce, R. J., Gourbal, B., Werkmeister, E., Colinet, D., Reichhart, J. M., ... Coustau, C. (2010). Involvement of the cytokine MIF in the snail host immune response to the parasite Schistosoma mansoni. PLoS Pathogens, 6(9), e1001115.

Bansal, R., Hulbert, S. H., Reese, J. C., Whitworth, R. J., Stuart, J. J., \& Chen, M. S. (2014). Pyrosequencing reveals the predominance of Pseudomonadaceae in gut microbiome of a gall midge. Pathogens, 3, 459-472.

Barr, K. L., Hearne, L. B., Briesacher, S., Clark, T. L., \& Davis, G. E. (2010). Microbial symbionts in insects influence down-regulation of defense genes in maize. PLoS One, 5, e11339.

Baumann, P. (2005). Biology bacteriocyte-associated endosymbionts of plant sap-sucking insects. Annual Review of Microbiology, 59, 155-189.

Behmer, S. T. (2009). Insect herbivore nutrient regulation. Annual Review of Entomology, 54, 165-187.

Belliure, B., Janssen, A., Maris, P. C., Peters, D., \& Sabelis, M. W. (2005). Herbivore arthropods benefit from vectoring plant viruses. Ecology Letters, 8, 70-79.

Ben-Yosef, M., Pasternak, Z., Jurkevitch, E., \& Yuval, B. (2015). Symbiotic bacteria enable olive fly larvae to overcome host defences. Royal Society Open Science, 2, 150170.

Biere, A., \& Bennett, A. E. (2013). Three-way interactions between plants, microbes and insects. Functional Ecology, 27, 567-573.

Body, M., Kaiser, W., Dubreuil, G., Casas, J., \& Giron, D. (2013). Leaf-miners co-opt microorganisms to enhance their nutritional environment. Journal of Chemical Ecology, 39, 969-977. 
Boivin, T., Henri, H., Vavre, F., Gidoin, C., Veber, P., Candau, J. N., ... AugerRozenberg, M. A. (2014). Epidemiology of asexuality induced by the endosymbiotic Wolbachia across phytophagous wasp species: Host plant specialization matters. Molecular Ecology, 23, 2362-2375.

Boone, C. K., Keefover-Ring, K., Mapes, A. C., Adams, A. S., Bohlmann, J., \& Raffa, K. F. (2013). Bacteria associated with a tree-killing insect reduce concentrations of plant defense compounds. Journal of Chemical Ecology, 39, 1003-1006.

Bordenstein, S. R., O'Hara, F. P., \& Werren, J. H. (2001). Wolbachia-induced incompatibility precedes other hybrid incompatibilities in Nasonia. Nature, 409, 707-710.

Boto, L. (2014). Horizontal gene transfer in the acquisition of novel traits by metazoans. Proceedings of the Royal Society B-Biological Sciences, 281. http://dx.doi.org/10.1098/ rspb.2013.2450.

Bourtzis, K., Lees, R. S., Hendrichs, J., \& Vreysen, M. J. B. (2016). More than one rabbit out of the hat: Radiation, transgenic and symbiont-based approaches for sustainable management of mosquito and tsetse fly populations. Acta Tropica, 157, 115-130.

Bouvaine, S., Boonham, N., \& Douglas, A. E. (2011). Interactions between a luteovirus and the GroEL chaperonin protein of the symbiotic bacterium Buchnera aphidicola of aphids. Journal of General Virology, 92, 1467-1474.

Bressan, A. (2014). Emergence and evolution of Arsenophonus bacteria as insect-vectored plant pathogens. Infection, Genetics and Evolution, 22, 81-90.

Broderick, N. A., Raffa, K. F., Goodman, R. M., \& Handelsman, J. (2004). Census of the bacterial community of the gypsy moth larval midgut by using culturing and cultureindependent methods. Applied and Environmental Microbiology, 70, 293-300.

Brucker, R. M., \& Bordenstein, S. R. (2012). Speciation by symbiosis. Trends in Ecology \& Evolution, 27, 443-451.

Brucker, R. M., \& Bordenstein, S. R. (2013). The hologenomic basis of speciation: Gut bacteria cause hybrid lethality in the genus Nasonia. Science, 341, 667-669.

Brune, A., \& Dietrich, C. (2015). The gut microbiota of termites: Digesting the diversity in the light of ecology and evolution. Annual Review of Microbiology, 69, 145-166.

Buchner, P. (1965). Endosymbiosis of animals with plant microorganisms. New York.

Calandra, T., \& Roger, T. (2003). Macrophage migration inhibitory factor: A regulator of innate immunity. Nature Reviews Immunology, 3(10), 791-800.

Calderon-Cortes, N., Quesada, M., Watanabe, H., Cano-Camacho, H., \& Oyama, K. (2012). Endogenous plant cell wall digestion: A key mechanism in insect evolution. Annual Review of Ecology, Evolution and Systematics, 43, 45-71.

Caspi-Fluger, A., Inbar, M., Mozes-Daube, N., Katzir, N., Portnoy, V., Belausov, E., ... Zchori-Fein, E. (2012). Horizontal transmission of the insect symbiont Rickettsia is plant-mediated. Proceedings of the Royal Society B: Biological Sciences, 279, 1791-1796.

Cattel, J., Martinez, J., Jiggins, F. M., Mouton, L., \& Gibert, P. (2016). Wolbachia-mediated protection against viruses in the invasive pest Drosophila suzukii. Insect Molecular Biology. http://dx.doi.org/10.1111/imb.12245.

Chaudhary, R., Atamiana, H. S., Shenc, Z., Briggsc, S. P., \& Kaloshian, I. (2014). GroEL from the endosymbiont Buchnera aphidicola betrays the aphid by triggering plant defense. Proceedings of the National Academy of Sciences of the United States of America, 111, 8919-8924.

Chiel, E., Zchori-Fein, E., Inbar, M., Gottlieb, Y., Adachi-Hagimori, T., Kelly, S. E., ... Hunter, M. S. (2009). Almost there: Transmission routes of bacterial symbionts between trophic levels. PLoS One, 4, e4767.

Chu, C. C., Spencer, J. L., Curzi, M. J., Zavala, J. A., \& Seufferheld, M. J. (2013). Gut bacteria facilitate adaptation to crop rotation in the western corn rootworm. Proceedings of the National Academy of Sciences of the United States of America, 110, 11917-11922. 
Chuche, J., Danet, J.-L., Salar, P., Foissac, X., \& Thiéry, D. (2016). Transmission of 'Candidatus Phytoplasma solani' by Reptalus quinquecostatus (Hemiptera: Cixiidae). Annals of Applied Biology, 169, 214-223. http://dx.doi.org/10.1111/aab.12291.

Chung, S. H., Rosa, C., Scully, E. D., Peiffer, M., Tooker, J. F., Hoover, K., ... Felton, G. W. (2013). Herbivore exploits orally secreted bacteria to suppress plant defenses. Proceedings of the National Academy of Sciences of the United States of America, 110, 15728-15733.

Cobbs, C., Heath, J., Stireman, J. O., \& Abbot, P. (2013). Carotenoids in unexpected places: Gall midges, lateral gene transfer, and carotenoid biosynthesis in animals. Molecular Phylogenetics and Evolution, 68, 221-228.

Colman, D. R., Toolson, E. C., \& Takacs-Vesbach, C. D. (2012). Do diet and taxonomy influence insect gut bacterial communities? Molecular Ecology, 21, 5124-5137.

Cornell, H. V. (1983). The secondary chemistry and complex morphology of galls formed by the Cynipinae (Hymenoptera): Why and how? The American Midland Naturalist Journal, 110, 225-234.

Cryan, J. R., \& Urban, J. M. (2012). Higher-level phylogeny of the insect order Hemiptera: Is Auchenorrhyncha really paraphyletic? Systematic Entomology, 37, 7-21.

Daimon, T., Taguchi, T., Meng, Y., Katsuma, S., Mita, K., \& Shimada, T. (2008). Beta-fructofuranosidase genes of the silkworm, Bombyx mori: Insights into enzymatic adaptation of B. mori to toxic alkaloids in mulberry latex. The Journal of Biological Chemistry, 283, 15271-15279.

Degnan, P. H., \& Moran, N. A. (2008). Diverse phage-encoded toxins in a protective insect endosymbiont. Applied and Environmental Microbiology, 74, 6782-6791.

Dicke, M., van Loon, J. J. A., \& Soler, R. (2009). Chemical complexity of volatiles from plants induced by multiple attack. Nature Chemical Biology, 5, 317-324.

Douglas, A. E. (2013). Microbial brokers of insect-plant interactions revisited. Journal of Chemical Ecology, 39, 952-961.

Dowd, P. F., \& Shen, S. K. (2011). The contribution of symbiotic yeast to toxin resistance of the cigarette beetle (Lasioderma serricorne). Entomological Experimentalis et Applicata, 56, 241-248.

Dubreuil, G., Deleury, E., Crochard, D., Simon, J.-C., \& Coustau, C. (2014). Diversification of MIF immune regulators in aphids: Link with agonistic and antagonistic interactions. BMC Genomics, 15, 762 .

Duron, O., Bouchon, D., Boutin, S., Bellamy, L., Zhou, L., Engelstädter, J., \& Hurst, G. D. (2008). The diversity of reproductive parasites among arthropods: Wolbachia do not walk alone. BMC Biology, 6, 27.

Engel, P., \& Moran, N. A. (2013). The gut microbiota of insects - Diversity in structure and function. FEMS Microbiology Reviews, 37, 699-735.

Engelstädter, J., \& Hurst, G. D. D. (2009). The ecology and evolution of microbes that manipulate host reproduction. Annual Review of Ecology, Evolution and Systematics, 40, 127-149.

Erb, M., Meldau, S., \& Howe, G. A. (2012). Role of phytohormones in insect-specific plant reactions. Trends in Plant Science, 17, 250-259.

Ferrari, J., Darby, A. C., Daniell, T. J., Godfray, H. C. J., \& Douglas, A. E. (2004). Linking the bacteria community in pea aphids with host-plant use and natural enemy resistance. Ecological Entomology, 29, 60-65.

Ferrari, J., \& Vavre, F. (2011). Bacterial symbionts in insects or the story of communities affecting communities. Philosophical Transactions of the Royal Society B, 366, 1389-1400.

Fontana, A., Reichelt, M., Hempel, S., Gershenzon, J., \& Unsicker, S. B. (2009). The effects of arbuscular mycorrhizal fungi on direct and indirect defense metabolites of Plantago lanceolata L. Journal of Chemical Ecology, 35, 833-843. 
Frago, E., Dicke, M., \& Godfray, H. C. J. (2012). Insect symbionts as hidden players in insectplant interactions. Trends in Ecology \& Evolution, 27, 705-711.

Gehrer, L., \& Vorburger, C. (2012). Parasitoids as vectors of facultative bacterial endosymbionts in aphids. Biology Letters, 8, 613-615.

Giron, D., Frago, E., Glevarec, G., Pieterse, C. M. J., \& Dicke, M. (2013). Cytokinins as key regulators in plant-microbe-insect interactions: Connecting plant growth and defence. Functional Ecology, 27, 599-609.

Giron, D., \& Glevarec, G. (2014). Cytokinin-induced phenotypes in plant-insect interactions: Learning from the bacterial world. Journal of Chemical Ecology, 40, 826-835.

Giron, D., Huguet, E., Stone, G. N., \& Body, M. (2016). Insect-induced effects on plants and possible effectors used by galling and leaf-mining insects to manipulate their hostplant. Journal of Insect Physiology, 84, 70-89.

Gonella, E., Pajoro, M., Marzorati, M., Crotti, E., Mandrioli, M., Pontini, M., ... Daffonchio, D. (2015). Plant-mediated interspecific horizontal transmission of an intracellular symbiont in insects. Scientific Reports, 5, 15811.

Gottlieb, Y., Zchori-Fein, E., Mozes-Daube, N., Kontsedalov, S., Skaljac, M., Brumin, M., ... Ghanim, M. (2010). The transmission efficiency of tomato yellow leaf curl virus by the whitefly Bemisia tabaci is correlated with the presence of a specific symbiotic bacterium species. Journal of Virology, 84, 9310-9317.

Grbić, M., Van Leeuwen, T., Clark, R. M., Rombauts, S., Rouzé, P., Grbić, V.,... Hernández-Crespo, P. (2011). The genome of Tetranychus urticae reveals herbivorous pest adaptations. Nature, 479, 487-492.

Groen, S. C., Humphrey, P. T., Chevasco, D., Ausubel, F. M., Pierce, N. E., \& Whiteman, N. K. (2016). Pseudomonas syringae enhances herbivory by suppressing the reactive oxygen burst in Arabidopsis. Journal of Insect Physiology, 84, 90-102.

Guay, J. F., Boudreault, S., Michaud, D., \& Cloutier, C. (2009). Impact of environmental stress on aphid clonal resistance to parasitoids: Role of Hamiltonella defensa bacterial symbiosis in association with a new facultative symbiont of the pea aphid. Journal of Insect Physiology, 55, 919-926.

Gueguen, G., Vavre, F., Gnankine, O., Peterschmitt, M., Charif, D., Chiel, E., ... Fleury, F. (2010). Endosymbiont metacommunities, mtDNA diversity and the evolution of the Bemisia tabaci (Hemiptera: Aleyrodidae) species complex. Molecular Ecology, 19, 4365-4376.

Hackett, S. C., Karley, A. J., \& Bennett, A. E. (2013). Unpredicted impacts of insect endosymbionts on interactions between soil organisms, plants and aphids. Proceedings of the Royal Society B: Biological Sciences, 280, 2131275. http://dx.doi.org/10.1098/ rspb.2013.1275.

Hamilton, P. T., \& Perlman, S. J. (2013). Host defense via symbiosis in Drosophila. PLoS Pathogens, 9(12), e1003808.

Hansen, A. K., \& Moran, N. A. (2014). The impact of microbial symbionts on host plant utilization by herbivorous insects. Molecular Ecology, 23, 1473-1496.

Hedges, L. M., Brownlie, J. C., O’Neill, S. L., \& Johnson, K. N. (2008). Wolbachia and virus protection in insects. Science, 322, 702.

Heil, M., \& McKey, D. (2003). Protective ant-plant interactions as model systems in ecological and evolutionary research. Annual Review of Ecology, Evolution and Systematics, 34, 425-453.

Henry, L. M., Maiden, M. C. J., Ferrari, J., \& Godfray, H. C. J. (2015). Insect life history and the evolution of bacterial mutualism. Ecology Letters, 18, 516-525.

Henry, L. M., Peccoud, J., Simon, J.-C., Hadfield, J. D., Maiden, M. J. C., Ferrari, J., \& Godfray, H. C. J. (2013). Horizontally transmitted symbionts and host colonization of ecological niches. Current Biology, 23, 1713-1717. 
Himler, A. G., Adachi-Hagimori, T., Bergen, J. E., Kozuch, A., Kelly, S. E., Tabashnik, B. E., ... Hunter, M. S. (2011). Rapid spread of a bacterial symbiont in an invasive whitefly is driven by fitness benefits and female bias. Science, 332, 254-256.

Hoffmann, J. A., \& Reichhart, J. M. (2002). Drosophila innate immunity: An evolutionary perspective. Nature Immunology, 3, 121-126.

Hogenhout, S. A., van der Wilk, F., Verbeek, M., Goldbach, R. W., \& van den Heuvel, J. F. (1998). Potato leafroll virus binds to the equatorial domain of the aphid endosymbiotic GroEL homolog. Journal of Virology, 72, 358-365.

Hosokawa, T., Kikuchi, Y., Meng, X. Y., \& Fukatsu, T. (2005). The making of symbiont capsule in the plataspid stinkbug Megacopta punctatissima. FEMS Microbiology Ecology, 54, 471-477.

Hosokawa, T., Kikuchi, Y., Shimada, M., \& Fukatsu, T. (2007). Obligate symbiont involved in pest status of host insect. Proceedings of the Royal Society B-Biological Sciences, 274, 1979-1984.

Husnik, F., Nikoh, N., Koga, R., Ross, L., Duncan, R. P., Fujie, M., .. Von Dohlen, C. D. (2013). Horizontal gene transfer from diverse bacteria to an insect genome enables a tripartite nested mealybug symbiosis. Cell, 153, 1567-1578.

Ingwell, L. L., Eigenbrode, S. D., \& Bosque-Pérez, N. A. (2012). Plant viruses alter insect behavior to enhance their spread. Scientific Reports, 2, 578. http://dx.doi.org/10.1038/ srep00578.

Janson, E. M., Stireman, J. O., Singer, M. S., \& Abbot, P. (2008). Phytophagous insectmicrobe mutualisms and adaptive evolutionary diversification. Evolution, 62, 997-1012.

Jones, R. T., Sanchez, L. G., \& Fierer, N. (2013). A cross-taxon analysis of insect-associated bacterial diversity. PLoS One, 8(4), e61218.

Kaiser, W., Huguet, E., Casas, J., Commin, C., \& Giron, D. (2010). Plant green-island phenotype induced by leaf-miners is mediated by bacterial symbionts. Proceedings of the Royal Society B-Biological Sciences, 277, 2311-2319.

Kaltenpoth, M., Winter, S. A., \& Kleinhammer, A. (2009). Localization and transmission route of Coriobacterium glomerans, the endosymbiont of pyrrhocorid bugs. FEMS Microbiology Ecology, 69, 373-383.

Kikuchi, Y., Hosokawa, T., \& Fukatsu, T. (2007). Insect-microbe mutualism without vertical transmission: A stinkbug acquires a beneficial gut symbiont from the environment every generation. Applied and Environmental Microbiology, 73, 4308-4316.

Kirsch, R., Gramzow, L., Theißen, G., Siegfried, B. D., Ffrench-Constant, R. H., Heckel, D. G., \& Pauchet, Y. (2014). Horizontal gene transfer and functional diversification of plant cell wall degrading polygalacturonases: Key events in the evolution of herbivoryin beetles. Insect Biochemistry and Molecular Biology, 52, 33-50.

Kirsch, R., Heckel, D. G., \& Pauchet, Y. (2016). How the rice weevil breaks down the pectin network: Enzymatic synergism and sub-functionalization. Insect Biochemistry and Molecular Biology, 71, 72-82.

Kliot, A., Cilia, M., Czosnek, H., \& Ghanim, M. (2014). Implication of the bacterial endosymbiont Rickettsia spp. in interactions of the whitefly Bemisia tabaci with tomato yellow leaf curl virus. Journal of Virology, 88, 5652-5660.

Koehncke, A., Telschow, A., \& Kondoh, M. (2012). Invasibility as an emergent property of native metapopulation structure. Oikos, 122, 332-340.

Kostovcik, M., Bateman, C. C., Kolarik, M., Stelinski, L. L., Jordal, B. H., \& Hulcr, J. (2015). The ambrosia symbiosis is specific in some species and promiscuous in others: Evidence from community pyrosequencing. ISME Journal, 9, 126-138.

Laughton, A. L., Fan, M. H., \& Gerardo, N. M. (2014). Combined effects of symbionts and ageing on life history traits in the pea aphid, Acyrthosiphon pisum. Applied and Environmental Microbiology, 80, 470-477. 
Lewis, Z., \& Lizé, A. (2015). Insect behaviour and the microbiome. Current Opinion in Insect Science, 9, 86-90.

Lieutier, F., Bermudez-Torres, K., Cook, J., Harris, M. O., Legal, L., Sallé, A., ... Giron, D. (2017). From plant exploitation to mutualism. In N. Sauvion, D. Thiery, \& P. A. Calatayud (Eds.), Insect-Plant Interactions in a Crop Protection Perspective (Vol. 81, pp. 55-109).

Lizé, A., McKay, R., \& Lewis, Z. (2013). Gut microbiota and kin recognition. Trends in Ecology \& Evolution, 28, 325-326.

Lizé, A., McKay, R., \& Lewis, Z. (2014). Kin recognition in Drosophila: The importance of ecology and gut microbiota. ISME Journal, 8, 469-477.

Luan, J. B., Chen, W., Hasegawa, D. K., Simmons, A. M., Wintermantel, W. M., Ling, K. S., ... Douglas, A. E. (2015). Metabolic coevolution in the bacterial symbiosis of whiteflies and related plant sap-feeding insects. Genome Biology and Evolution, 7, 2635-2647. http://dx.doi.org/10.1093/gbe/evv170.

Luan, J. B., Yao, D. M., Zhang, T., Walling, L. L., Yang, M., Wang, Y. J., \& Liu, S. S. (2013). Suppression of terpenoid synthesis in plants by a virus promotes its mutualism with vectors. Ecology Letters, 16, 390-398.

Łukasik, P., van Asch, M., Guo, H., Ferrari, J., \& Godfray, H. C. J. (2013). Unrelated facultative endosymbionts protect aphids against a fungal pathogen. Ecology Letters, 16, 214-218.

Eukasik, P., Dawid, M. A., Ferrari, J., \& Godfray, H. C. J. (2013). The diversity and fitness effects of infection with facultative endosymbionts in the grain aphid, Sitobion avenae. Oecologia, 173, 985-996.

Łukasik, P., Guo, H., van Asch, M., Henry, L. M., Godfray, H. C. J., \& Ferrar, J. (2015). Horizontal transfer of facultative endosymbionts is limited by host relatedness. Evolution, 69, 2757-2766.

Manzano-Marín, A., Simon, J.-C., \& Latorre, A. (2016). Reinventing the wheel and making it round (but smaller) again: Evolutionary convergence in Buchnera-Serratia symbiotic consortia between the distantly related aphids Tuberolachnus salignus (Lachninae, Lachnini) and Cinara cedri (Lachninae, Eulachnini). Genome Biology and Evolution, 8, 1440-1458. http://dx.doi.org/10.1093/gbe/evw085.

McCutcheon, J. P., McDonald, B. R., \& Moran, N. A. (2009). Convergent evolution of metabolic roles in bacterial co-symbionts of insects. Proceedings of the National Academy of Sciences of the United States of America, 106, 15394-15399.

McLean, A. H. C., van Asch, M., Ferrari, J., \& Godfray, H. C. J. (2011). Effects of bacterial secondary symbionts on host plant use in pea aphids. Proceedings of the Royal Society B-Biological Sciences, 278, 760-766.

Medina, R. F., Nachappa, P., \& Tamborindeguy, C. (2011). Differences in bacterial diversity of host-associated populations of Phylloxera notabilis Pergande (Hemiptera: Phylloxeridae) in pecan and water hickory. Journal of Evolutionary Biology, 24, 761-771.

Merville, A., Venner, S., Henri, H., Vallier, A., Menu, F., Vavre, F., ... Bel-Venner, M.-C. (2013). Endosymbiont diversity among sibling weevil species competing for the same resource. BMC Evolutionary Biology, 13, 28. http://dx.doi.org/10.1186/1471-2148-13-28.

Miller, W. J., Ehrman, L., \& Schneider, D. (2010). Infectious speciation revisited: Impact of symbiont-depletion on female fitness and mating behavior of Drosophila paulistorum. PLoS Pathogens, 6, e1001214.

Montllor, C. B., Maxmen, A., \& Purcell, A. H. (2002). Facultative bacterial endosymbionts benefit pea aphids Acyrthosiphon pisum under heat stress. Ecological Entomology, 27, 189-195.

Moran, N. A., Degnan, P. H., Santos, S. R., Dunbar, H. E., \& Ochman, H. (2005). The players in a mutualistic symbiosis: Insects, bacteria, viruses, and virulence genes. Proceedings of the National Academy of Sciences of the United States of America, 102, 16919-16926.

Moran, N. A., \& Jarvik, T. (2010). Lateral transfer of genes from fungi underlies carotenoid production in aphids. Science, 328, 624-627. 
Moran, N. A., McCutcheon, J. P., \& Nakabachi, A. (2008). Genomics and evolution of heritable bacterial symbionts. Annual Review of Genetics, 42, 165-190.

Morin, S., Ghanim, M., Zeidan, M., Czosnek, H., Verbeek, M., \& van den Heuvel, J. F. (1999). A GroEL homologue from endosymbiotic bacteria of the whitefly Bemisia tabaci is implicated in the circulative transmission of tomato yellow leaf curl virus. Virology, 256, 75-84.

Mueller, U. G., Gerardo, N. M., Aanen, D. K., Six, D. L., \& Schultz, T. R. (2005). The evolution of agriculture in insects. Annual Review of Ecology, Evolution and Systematics, 36, 563-595. Retrieved from http://www.jstor.org/stable/30033817.

Naessens, E., Dubreuil, G., Giordanengo, P., Baron, O. L., Minet-Kebdani, N., Keller, H., \& Coustau, C. A. (2015). Secreted MIF cytokine enables aphid feeding and represses plant immune responses. Current Biology, 25, 1898-1903.

Nikoh, N., McCutcheon, J. P., Kudo, T., Miyagishima, S. Y., Moran, N. A., \& Nakabachi, A. (2010). Bacterial genes in the aphid genome: Absence of functional gene transfer from Buchnera to its host. PLoS Genetics, 6(2), e1000827.

Novotny, V., Basset, Y., Miller, S. E., Weiblen, G. D., Bremer, B., Cizek, L., \& Drozd, P. (2002). Low host specificity of herbivorous insects in a tropical forest. Nature, 416, $841-844$.

Oliver, K. M., Degnan, P. H., Burke, G. R., \& Moran, N. A. (2010). Facultative symbionts in aphids and the horizontal transfer of ecologically important traits. Annual Review of Entomology, 55, 247-266. http://dx.doi.org/10.1146/annurev-ento-112408-085305.

Oliver, K. M., Russell, J. A., Moran, N. A., \& Hunter, M. S. (2003). Facultative bacterial symbionts in aphids confer resistance to parasitic wasps. Proceedings of the National Academy of Sciences of the United States of America, 100, 1803-1807.

Oliver, K. M., Smith, A. H., \& Russell, J. A. (2014). Defensive symbiosis in the real world -advancing ecological studies of heritable, protective bacteria in aphids and beyond. Functional Ecology, 28, 341-355.

Patot, S., Allemand, R., Fleury, F., \& Varaldi, J. (2012). An inherited virus influences the coexistence of parasitoid species through behaviour manipulation. Ecology Letters, 15, 603-610.

Peccoud, J., Ollivier, A., Plantegenest, M., \& Simon, J.-C. (2009). A continuum of genetic divergence from sympatric host races to species in the pea aphid complex. Proceedings of the National Academy of Sciences of the United States of America, 106, 7495-7500.

Perotti, M. A., Allen, J. M., Reed, D. L., \& Braig, H. R. (2007). Host-symbiont interactions of the primary endosymbiont of human head and body lice. The FASEB Journal, 21, 1058-1066.

Pinheiro, P. V., Kliot, A., Ghanim, M., \& Cilia, M. (2015). Is there a role for symbiotic bacteria in plant virus transmission by insects? Current Opinion in Insect Science, 8, 69-78.

Polin, S., Le Gallic, J. F., Simon, J.-C., Tsuchida, T., \& Outreman, Y. (2015). Conditional reduction of predation risk associated with a facultative symbiont in an insect. PLoS One, 10(11), e0143728.

Poulsen, M., Hu, H. F., Li, C., Chen, Z. S., Xu, L. H., Otani, S., ... Zhang, G. (2014). Complementary symbiont contributions to plant decomposition in a fungus-farming termite. Proceedings of the National Academy of Sciences of the United States of America, $111,14500-14505$.

Rao, Q., Rollat-Farnier, P.-A., Zhu, D. T., Santos-Garcia, D., Silva, F. J., Moya, A., ... Liu, S. S. (2015). Genome reduction and potential metabolic complementation of the dual endosymbionts in the whitefly Bemisia tabaci. BMC Genomics, 16, 226. http://dx.doi.org/10.1186/s12864-015-1379-6.

Raubenheimer, D., Simpson, S. J., \& Mayntz, D. (2009). Nutrition, ecology and nutritional ecology: Toward an integrated framework. Functional Ecology, 23, 4-16. 
Robert, C. A. M., Frank, D. L., Leach, K. A., Turlings, T. C., Hibbard, B. E., \& Erb, M. (2013). Direct and indirect plant defenses are not suppressed by endosymbionts of a specialist root herbivore. Journal of Chemical Ecology, 39, 507-515.

Rohfritsch, O. (2008). Plants, gall midges, and fungi: A three-component system. Entomological Experimentalis et Applicata, 128, 208-216.

Rollat-Farnier, P.-A., Santos-Garcia, D., Rao, Q., Sagot, M. F., Silva, F. J., Henri, H., ... Liu, S. S. (2015). Two host clades, two bacterial arsenals: Evolution through gene losses in facultative endosymbionts. Genome Biology and Evolution, 7, 839-855.

Salem, H., Florez, L., Gerardo, N., \& Kaltenpoth, M. (2015). An out-of-body experience: The extracellular dimension for the transmission of mutualistic bacteria in insects. Proceedings of the Royal Society B-Biological Sciences, 282, 20142957.

Sanders, D., Kehoe, R., van Veen, F. F., McLean, A., Godfray, H. C. J., Dicke, M., ... Frago, E. (2016). Defensive insect symbiont leads to cascading extinctions and community collapse. Ecology Letters, 19, 789-799.

Schmid, M., Sieber, R., Zimmermann, Y. S., \& Vorburger, C. (2012). Development, specificity and sublethal effects of symbiont-conferred resistance to parasitoids in aphids. Functional Ecology, 26, 207-215.

Schmitz, A., Anselme, C., Ravallec, M., Rebuf, C., Simon, J.-C., Gatti, J.-L., \& Poirié, M. (2012). The cellular immune response of the pea aphid to foreign intrusion and symbiotic challenge. PLoS One, 7(7), e42114.

Schoonhoven, L. M., van Loon, J. J. A., \& Dicke, M. (2005). Insect-plant biology (2nd ed.). Oxford: Oxford University Press.

Schulenburg, H., Boehnisch, C., \& Michiels, N. K. (2007). How do invertebrates generate a highly specific innate immune response? Molecular Immunology, 44, 3338-3344.

Servedio, M. R., Doorn, G. S., van Kopp, M., Frame, A. M., \& Nosil, P. (2011). Magic traits in speciation: 'magic' but not rare? Trends in Ecology \& Evolution, 26, 389-397.

Sharon, G., Segal, D., Ringo, J. M., Hefetz, A., Zilber-Rosenberg, I., \& Rosenberg, E. (2010). Commensal bacteria play a role in mating preference of Drosophila melanogaster. Proceedings of the National Academy of Sciences of the United States of America, 107, 20051-20056.

Shoemaker, D. D., Katju, V., \& Jaenike, J. (1999). Wolbachia and the evolution of reproductive isolation between Drosophilla recens and Drosophila subquinaria. Evolution; International Journal of Organic Evolution, 53, 1157-1164.

Simon, J.-C., Boutin, S., Tsuchida, T., Koga, R., Gallic, J. F., Frantz, A., ... Fukatsu, T. (2011). Facultative symbiont infections affect aphid reproduction. PLoS One, 6, e21831.

Slansky, F., Jr., \& Rodriguez, J. G. (1987). Nutritional ecology of insects, mites, spiders, and related invertebrates. New-York: John Wiley.

Soucy, S. M., Huang, J., \& Gogarten, J. P. (2015). Horizontal gene transfer: Building the web of life. Nature Reviews Genetics, 16, 472-482.

Stafford, C. A., Walker, G. P., \& Ullman, D. E. (2011). Infection with a plant virus modifies vector feeding behavior. Proceedings of the National Academy of Sciences of the United States of America, 108, 9350-9355.

Su, Q., Oliver, K. M., Pan, H., Jiao, X., Liu, B., Xie, W., ... Zhou, X. (2013). Facultative symbiont Hamiltonella confers benefits to Bemisia tabaci (Hemiptera: Aleyrodidae), an invasive agricultural pest worldwide. Environmental Entomology, 42, 1265-1271.

Su, Q., Oliver, K. M., Xie, W., Wu, Q., Wang, S., \& Zhang, Y. (2015). The whiteflyassociated facultative symbiont Hamiltonella defensa suppresses induced plant defences in tomato. Functional Ecology, 29, 1007-1018.

Sugio, A., Dubreuil, G., Giron, D., \& Simon, J.-C. (2015). Plant-insect interactions under bacterial influence: Ecological implications and underlying mechanisms. Journal of Experimental Botany, 66, 467-478. 
Sun, B. F., Xiao, J. H., He, S. M., Liu, L., Murphy, R. W., \& Huang, D. W. (2013). Multiple ancient horizontal gene transfers and duplications in lepidopteran species. Insect Molecular Biology, 22, 72-87.

Toju, H., \& Fukatsu, T. (2011). Diversity and infection prevalence of endosymbionts in natural populations of the chestnut weevil: Relevance of local climate and host plants. Molecular Ecology, 20, 853-868.

Toju, H., Tanabe, A. S., Notsu, Y., Sota, T., \& Fukatsu, T. (2013). Diversification of endosymbiosis: Replacements, co-speciation and promiscuity of bacteriocyte symbionts in weevils. ISME Journal, 7, 1378-1390.

Tsuchida, T., Koga, R., Fujiwara, A., \& Fukatsu, T. (2014). Phenotypic effect of 'Candidatus Rickettsiella viridis', a facultative symbiont of the pea aphid (Acyrthosiphon pisum), and its interaction with a coexisting symbiont. Applied and Environmental Microbiology, 80, 525-533.

Tsuchida, T., Koga, R., \& Fukatsu, T. (2004). Host plant specialization governed by facultative symbiont. Science, 303, 1989.

Vavre, F., Fleury, F., Lepetit, D., Fouillet, P., \& Bouletreau, M. (1999). Phylogenetic evidence for horizontal transmission of Wolbachia in host-parasitoid associations. Molecular Biology and Evolution, 16, 1711-1723.

Vavre, F., \& Kremer, N. (2014). Microbial impacts on insect evolutionary diversification: From patterns to mechanisms. Current Opinion in Insect Science, 4, 29-34.

Visotto, L. E., Oliveira, M. G. A., Guedes, R. N. C., Ribon, A. O. B., \& Good-God, P. I. V. (2009). Contribution of gut bacteria to digestion and development of the velvetbean caterpillar, Anticarsia gemmatalis. Journal of Insect Physiology, 55, 185-191.

Vorburger, C., Gehrer, L., \& Rodriguez, P. (2010). A strain of the bacterial symbiont Regiella insecticola protects aphids against parasitoids. Biology Letters, 6, 109-111.

Wagner, S. M., Martinez, A. J., Ruan, Y. M., Kim, K. L., Lenhart, P. A., Dehnel, A. C., ... White, J. A. (2015). Facultative endosymbionts mediate dietary breadth in a polyphagous herbivore. Functional Ecology, 29, 1402-1410.

Werren, J. H., Baldo, L., \& Clark, M. E. (2008). Wolbachia: Master manipulators of invertebrate biology. Nature Reviews Microbiology, 6, 741-751.

Wybouw, N., Dermauw, W., Tirry, L., Stevens, C., Grbić, M., Feyereisen, R., \& van Leeuwen, T. (2014). A gene horizontally transferred from bacteria protects arthropods from host plant cyanide poisoning. eLife, 3, e02365.

Xie, J., Vilchez, I., \& Mateos, M. (2010). Spiroplasma bacteria enhance survival of Drosophila hydei attacked by the parasitic wasp Leptopilina heterotoma. PLoS One, 5, e12149.

Zabalou, S., Riegler, M., Theodorakopoulou, M., Stauffer, C., Savakis, C., \& Bourtzis, K. (2004). Wolbachia-induced cytoplasmic incompatibility as a means for insect pest population control. Proceedings of the National Academy of Sciences of the United States of America, 101, 15042-15045.

Zarate, S. I., Kempema, L. A., \& Walling, L. L. (2007). Silverleaf whitefly induces salicylic acid defenses and suppresses effectual jasmonic acid defenses. Plant Physiology, 143, $866-875$.

Zhang, H., de Bernonville, T. D., Body, M., Glevarec, G., Reichelt, M., Unsicker, S., ... Giron, D. (2016). Leaf-mining by Phyllonorycter blancardella reprograms the host-leaf transcriptome to modulate phytohormones associated with nutrient mobilization and plant defense. Journal of Insect Physiology, 84, 114-127.

Zhao, C., Escalante, L. N., Chen, H., Benatti, T. R., Qu, J., Chellapilla, S., ... Batterton, M. (2015). A massive expansion of effector genes underlies gall-formation in the wheat pest Mayetiola destructor. Current Biology, 25, 613-620.

Zhu, F., Poelman, E. H., \& Dicke, M. (2014). Insect herbivore-associated organisms affect plant responses to herbivory. New Phytologist, 204, 315-321. 


\section{Contents}

Plant-Insect Interactions: A Paleontological and an Evolutionary Perspective B. Schatz, N. Sauvion, F. Kjellberg and A. Nel

Evolution of Plant-Insect Interactions: Insights From Macroevolutionary Approaches in Plants and Herbivorous Insects

G.J. Kergoat, A.S. Meseguer and E. Jousselin

From Plant Exploitation to Mutualism

F. Lieutier, K. Bermudez-Torres, J. Cook, M.O. Harris, L. Legal, A. Sallé, B. Schatz and D. Giron

Food Webs and Multiple Biotic Interactions in Plant-Herbivore Models

E. Corcket, B. Giffard and R.F.H. Sforza

Chemical Signatures in Plant-Insect Interactions

B. Frérot, E. Leppik, A.T. Groot, M. Unbehend and J.K. Holopainen

The Plant as a Habitat for Entomophagous Insects

L. Kaiser, P. Ode, S. van Nouhuys, P.-A. Calatayud, S. Colazza, A.-M. Cortesero, A. Thiel and J.van Baaren

Influence of Microbial Symbionts on Plant-Insect Interactions

D. Giron, F. Dedeine, G. Dubreuil, E. Huguet, L. Mouton, Y. Outreman, F. Vavre

and J.-C.Simon

How Host Plant and Fluctuating Environments Affect Insect Reproductive Strategies?

J. Moreau, E. Desouhant, P. Louâpre, M. Goubault, E. Rajon, A. Jarrige, F. Menu, and D. Thiéry

Plant-Insect Interactions in a Changing World

S. Pincebourde, J. van Baaren, S. Rasmann, P. Rasmont, G. Rodet, B. Martinet

and P.-A. Calatayud

Conservation Biological Control in Agricultural Landscapes

A. Rusch, R. Bommarco and B. Ekbom

Cover Image: The Hazel Leaf-roller Weevil, Apoderus coryli (Linnaeus, 1758) (Coleoptera: Curculionidae: Attelabinae), a primitive weevil that can reach a length of 6-8 millimetres $(0.24-0.31$ in).

Théotime Colinc)
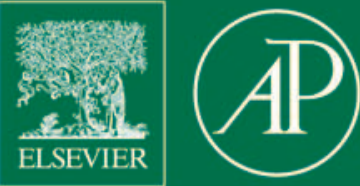

ACADEMIC PRESS

An imprint of Elsevier

elsevier.com

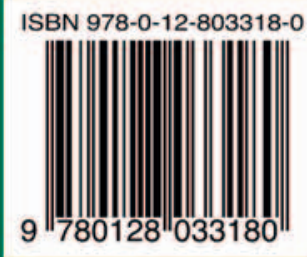

